Article

\title{
Perfect for the Job? Overqualification of Immigrants and their Descendants in the Norwegian Labor Market
}

\author{
Edvard N. Larsen*, Adrian F. Rogne and Gunn E. Birkelund \\ Department of Sociology and Human Geography, University of Oslo, 0317 Oslo, Norway; E-Mails: e.n.larsen@sosgeo.uio.no \\ (E.N.L.), a.f.rogne@sosgeo.uio.no (A.F.R.), g.e.birkelund@sosgeo.uio.no (G.E.B.) \\ * Corresponding author
}

Submitted: 28 February 2018 | Accepted: 30 May 2018 | Published: 30 July 2018

\begin{abstract}
Compared to the majority population, studies have shown that non-western immigrants are more likely to work in jobs for which they are overqualified. These findings are based on coarse measures of jobs, and an important question is how sensitive these findings are to the definition of jobs. By using detailed information from Norwegian register data 2014, we provide a methodological innovation in comparing individuals working in the same occupation, industry, sector, firm, and municipality. In this way, we measure the degree of overqualification among workers within more than 653,000 jobs. We differentiate between immigrants and their descendants originating from Western Europe, the New EU countries, other Western countries, the Middle East and North Africa (MENA), Africa and Asia (except MENA countries), and South and Central America, and compare their outcomes with the majority population holding the same jobs. We find that immigrants from all country of origin groups are more likely to be overqualified compared to the majority population and to descendants of immigrants. However, the prevalence of overqualification decreases with time since immigration.
\end{abstract}

\section{Keywords}

inequality; integration; labor markets; migration; overqualification

\section{Issue}

This article is part of the issue "The Race for Highly-Skilled Workers", edited by Neli Demireva (University of Essex, UK) and Ivana Fellini (University of Milano Bicocca, Italy).

(C) 2018 by the authors; licensee Cogitatio (Lisbon, Portugal). This article is licensed under a Creative Commons Attribution 4.0 International License (CC BY).

\section{Introduction}

Overqualification refers to a mismatch between the required qualifications for a given job, or the general educational level of individuals holding a job, and the qualifications held by the individual job occupant. Economies characterized by mismatches in the labor market are less efficient and productive, as human capital is underutilized. In addition to being harmful from a macroeconomic perspective, overqualification is associated with lower economic returns to human capital for the individuals in question. The successful utilization of human capital is perhaps of particular interest in the context of migration: compared to the majority population, immigrants in Western countries are not only more likely to be unemployed, but also more likely to hold jobs for which they are overqualified (Green, Kler, \& Leeves, 2007; Lindley, 2009; OECD, 2008). Such systematic differences in overqualification between immigrants and the majority may result from various mechanisms, such as discrimination, lack of recognition of qualifications obtained in foreign countries, or differences in access to informal networks and employment opportunities.

In this study, we provide a thorough analysis of overqualification among immigrants and descendants of immigrants in Norway. By using Norwegian registry data from 2014, we provide a fine-grained overview of relative overqualification among immigrants and descendants from different regions of origin. We use different measurements of relative overqualification (the mean, 
modal, and median approach) at different levels of detail ranging from coarse job definitions (commonly used in the literature), to very detailed job categories. This is motivated by the possibility that coarse job definitions, such as simple ISCO-codes, may bias estimates of overqualification due to heterogeneous occupational positions being treated as identical. We compare people working in the same occupation, sector, industry, firm, and municipality, resulting in more than 653,000 unique jobs. To the best of our knowledge, an approach with this level of detail has never been used before. The methodological contribution of this article is thus twofold: we investigate whether group differences in relative overqualification persist when comparing individuals in nearly identical occupational positions, and whether the results are influenced by the choice of measurement.

We seek to investigate three main research questions: are immigrants and descendants from different countries of origin more or less likely to be overqualified, compared to majority Norwegians? How do these differences vary with method for assessing overqualification or definition of jobs? How do these differences vary between gender, sectors, time since immigration, and educational level?

\section{Background}

There is a growing strand of literature showing that the marginal returns to education tend to be lower for immigrants than the majority (Bratsberg \& Terrell, 2002; Chiswick \& Miller, 2008; Lindley, 2009). A potential mechanism explaining these differences might be that immigrants are more likely to be overqualified for their jobs. This is indeed the partial conclusion of studies conducted in Norway: Hardoy and Schøne (2014) find that a substantial part of the difference in returns to education among non-western immigrants and the majority can be attributed to a higher prevalence of overqualification among immigrants. Villund $(2010,2014)$ has also documented a higher prevalence of overqualification among immigrants than the majority in Norway, and several studies have documented that immigrants in Norway are more likely than the majority population to be unemployed, in particular immigrants from non-Western countries (e.g., Bratsberg, Raaum, \& Røed, 2014).

Potential causes of overqualification among immigrants could be related to lack of relevant work experience in the host country, problems with recognition of skills obtained before migration, and language proficiency issues (Duvander, 2001). Even when formally recognized, immigrants' pre-immigration education and work experience might be less valued in their new country of residence (Zeng \& Xie, 2004), particularly if employers are queuing the job applicants by their potential productivity (Weiss, 1980). Immigrants might also lack country-specific skills that could affect their employment opportunities and their likelihood to get jobs they are formally qualified for. An Australian study showed that immigrants who have been overqualified in their country of origin were more likely to be overqualified in their new country of residence (Piracha, Tani, \& Vadean, 2012). Additionally, immigrants with different reasons for migration might have strongly differing opportunities regarding employment: those who potentially face remigration might not be able to turn down jobs for which they are overqualified, in contrast to majority candidates. None of the mechanisms discussed so far, however, apply to descendants of immigrants, who, for the most part, have domestic education and work experience.

A group of mechanisms that may explain relative overqualification revolve around employer preferences and behavior. Ethnic discrimination, both of first- and second-generation of immigrant descent, has been documented through experimental studies (for overviews see OECD, 2013; Zschirnt \& Ruedin, 2016; for Norwegian studies see Birkelund, Chan, Ugreninov, Midtbøen, \& Rogstad, 2018; Birkelund, Heggeb $\varnothing, \&$ Rogstad, 2017; Midtbøen, 2016). When hired, minority candidates might need stronger qualifications to be considered on an equal footing with majority candidates, resulting in overqualification. Conversely, anticipating discrimination, ethnic minorities might seek jobs with lower formal requirements. Finally, network effects, information channels, and local labor market differences could also produce gaps in the incidence of overqualification between immigrants and the majority population.

There are potentially severe consequences of systematic overqualification. As mentioned, overqualification implies lower returns to education. In addition, the returns to excess education are lower than the returns to required education (i.e., Alba-Ramirez, 1993; Duncan \& Hoffman, 1981; Lindley, 2009; Nielsen, 2011; Rumberger, 1987). However, less is known about the long-term effects of initial labor market overqualification: having held positions beneath their skill level might present an employee as lacking in motivation or ambition to prospective employers, even if the initial overqualification was the result of external obstacles such as ethnic discrimination. Following this logic, systematic overqualification might lead to long-term stigma or cumulative disadvantage. Finally, it is in the interest of policy makers to limit overqualification because it leads to less effective use of skills, and a "productivity shortfall" (i.e., Barrett, Bergin, \& Duffy, 2006; Green et al., 2007). Highly educated individuals employed in positions where their human capital goes underutilized thus leads to a net loss of overall potential productivity. This topic is of particular relevance for policy makers in the context of immigration, where the utilization of immigrants' skills is considered to be crucial.

In this article, we aim to provide a thorough and detailed descriptive overview of relative overqualification in Norway that can serve as comparison for studies in other national contexts, as well as a basis for further studies, by assessing the relevance of methods, heterogeneity between immigrant groups, and heterogeneity within jobs. 


\section{Data and Methods}

\subsection{Data}

We rely on high-quality register data from Norwegian administrative registers, provided by Statistics Norway. These data contain demographic information on individuals (age, gender, country of origin, immigrant background etc.), as well as information on education and employment relations. The employment data provide information on every individual registered as working at least one hour in the reference week (in November), or who were temporarily absent from work.

The Norwegian-born majority is our reference group. Immigrants are defined as those who are born with two foreign-born parents to a mother not registered as resident in Norway at the time of birth. Descendants are defined as Norwegian-born with two foreign-born parents, the majority being those born in Norway with two Norwegian-born parents. We differentiate between immigrants and second-generation descendants originating from Western Europe, the New EU countries, other Western countries, MENA, South and Central America, Africa and Asia (except MENA countries). All others are placed in a residual category of "others" (e.g., individuals born abroad to two Norwegian-born parents). For descendants, the mother's country background is used if the parents have different country backgrounds.

The Norwegian educational registers include information on all education undertaken in Norway and formally approved education from abroad. However, for immigrants, the register information might be incomplete. For instance, immigrants with higher education may have stronger incentives to apply to get their foreign education approved by the Norwegian authorities and are thus more likely to register their educational level than immigrants with lower education are. If this is the case, our estimates of overqualification among immigrants might be upward-biased due to listwise deletion of individuals with no recorded educational level. The opposite would be true in the inverse case. To investigate this, we ran our main models twice, first we listwise deleted all individuals with missing educational information; second, we grouped these individuals with those who have no education or pre-school education (see Table A1 in the Annex). The latter approach should yield a conservative estimate of overqualification in groups where many individuals lack educational information, and large differences in the results from the two approaches would indicate that our data are biased due to a skewed distribution of missing educational levels. The results from the two approaches were almost identical. Thus, we are confident that this potential bias is not a major issue. However, the analyses in this article build on the second, more conservative approach.

Our sample includes all individuals between 25 and 64 years of age registered as resident in Norway in 2014, with a valid immigrant background indicator. From the employment data, we condition on having a non-missing indicator of whether the employment relation is the main employment relation, and having a non-missing occupational code, sector code, firm/organizational identification code ("business number"), and municipality of employment. To determine the modal, median, and mean education within each job (see Section 3.2 below), we use the education of all individuals who hold that job. Thus, individuals with multiple employment relations are included in the measurement of educational levels in all of their jobs. However, when assessing the relative overqualification of each individual, we use the main employment relation for these individuals. Finally, we condition on a successful merging of the data on demographics, education and employment, and not being currently enrolled in education. By conditioning on a successful merge with the employment data, we condition on being employed in the reference week. Our final samples differ somewhat between job definitions when using the modal approach. Table 2 shows descriptive statistics for the mean approach at the most detailed job definition. Descriptive statistics for the other samples are provided in Table A2.

\subsection{Measuring Overqualification}

There are at least three commonly used methods of operationalizing and measuring overqualification: job analysis, worker self-assessment, and realized matches (for an overview see Hartog, 2000). We have opted for the latter approach for this study. We use occupational data to map the distribution of qualifications among all individuals holding the same job as the individual in question. Using realized matches allows us to look at relative differences between groups even in cases where jobs have little or no formal requirements, or in cases where the same position in different sectors, industries, or firms have different actual skill distributions. In occupations where almost all employees exceed the formal requirements, there might still be systematic group differences in the de facto qualification distributions, which would not be identifiable with an approach based on job analysis. Thus, we argue that realized matches provide the best grounds for comparing inequalities in overqualification as an outcome. This strategy is, however, unsuited as an overall evaluation of the degree of qualification mismatch in the Norwegian labor market. Therefore, our results should be interpreted as measurements of relative, rather than absolute overqualification. Previous studies of overqualification using Norwegian data have employed all three measurements: Villund (2014) using

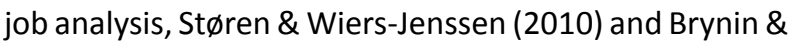
Longhi (2009) using worker self-assessment, and Hardoy \& Schøne (2014) using realized matches. Our results are thus only comparable with the latter.

We employ three methods to measure relative overqualification. First, we calculate the modal level of education for employees in each job using five ordinal 
educational levels (see Table A1 in the Annex). We define individuals as overqualified if their educational level is one or more levels higher than the modal education among individuals in the same job. ${ }^{1}$ Second, we use the mean length of education (in years) held by individuals in the same job (Verdugo \& Verdugo, 1989). Length of education (based on educational level, not actual time spent in education) approximately corresponds to the standard grade level of the NUS2000 educational codes. In this approach, an individual is overqualified if his/her education is more than one standard deviation above the job mean. As noted by Dolton \& Vignoles (2000, p. 180) the cutoff of one standard deviation is entirely arbitrary, yet we are primarily interested in the relative positions of different groups in the skill distributions of jobs, and do not see this as a problem, as we apply the same cutoff to all groups. The cutoff at one standard deviation above the mean is generally wider than the cutoff at one level above the mode or median, implying that the mean approach provides a more conservative estimate of the prevalence of relative overqualification. Third, we also measure the median level of education within each job, based on the same 5 -level classification as the modal level. We define individuals as overqualified if their educational level is one or more levels higher than the median education among individuals in the same job. ${ }^{2}$

\subsection{Defining a "Job"}

How a "job" is defined is of major importance for the assessment of relative overqualification. A coarse job definition, using heterogeneous jobs such as "teacher" or "secretary" may lead to an overestimation of the level of overqualification if there is heterogeneity in the educational requirements within the job. For instance, "teacher" may encompass a variety of occupations such as "preschool teacher", "adjunct", and "lector" associated with different levels of education. In this case, if most teachers were adjuncts, all lectors would be overqualified as teachers. If immigrant groups are unequally distributed on detailed occupational classifications, this may bias our estimates of relative overqualification between these groups. In addition, despite having the same occupational code, jobs may be heterogeneous in a number of other ways. First, firms in different industries or sectors hiring people for the same occupations may select candidates differently or hire from different pools of applicants. Thus, we measure overqualification within industries and sectors. Second, individual firms within the same sector and industry may regard the educational demands or the respective pools of applicants differently, also for jobs in the same occupation. To avoid this issue, we also measure overqualification within firms in the same industry and sector. Third, there may be regional differences in hiring practices or applicant pools, even within the same firm. For instance, if a fast-food chain has two restaurants, one in a city, and one in a rural area, the educational level and immigrant group composition of individuals applying for similar jobs at the two restaurants may vary greatly. To overcome this, we also measure overqualification within firms within the same municipalities.

In sum, differences in local labor markets, job requirements, the educational level of job applicants, hiring practices, rules and norms for advancement and promotion, and numerous other sources of occupational heterogeneity may bias estimates of the total prevalence of overqualification. If such systematic differences also correlate with the proportion of individuals from different immigrant groups within occupations, estimates of group differences in relative overqualification will be biased. A key contribution of the present study is the use of detailed information on occupations, which enables us to define a "job" as a set of relatively homogenous employment relations. To ensure that jobs are as homogenous as possible, we narrow down the definition of jobs in a stepwise fashion. This allows us to assess overqualification by comparing the education of each individual to the educational composition of others in jobs that are as similar as possible to their own while also exploring at which level (occupation, industry, sector, firm, and municipality) biases might occur due to occupational heterogeneity. It is important to acknowledge, however, that increasing the occupational detail in measuring overqualification potentially obscures important sources of ethnic disadvantage caused by occupational segregation. Immigrants and majority employees with equal qualifications might for instance hold substantially similar but formally distinct job titles, where the latter group is advantaged due to e.g., ethnic discrimination. In the same way, equally qualified immigrants might be stationed in certain branches of firms, thus not appearing to be relatively overqualified in our analysis. Such differences are effectively eliminated with our approach but remain potentially important sources of inequality in reality.

The Norwegian register data contains 452 unique broad occupational codes (4-digit) and 7073 unique narrow occupational codes (7-digit). We first utilize the entire list of broad and narrow occupational codes and regard each occupation as a unique job. Second, we utilize the entire list of industries in the Norwegian register data (780 industries) and define a job as the combination of occupational code and industry code. Third, to account for job heterogeneity between sectors and industries we define jobs as a combination of occupation, industry, and sector (24 institutional sectors). Fourth, to compare individuals within firms we use firm identification codes (there are 191,260 unique firms in our data).

\footnotetext{
${ }^{1}$ If there is no modal level of education within a job, but two adjacent modal levels, we set the modal to the midpoint between the two. If the two or more modal levels are not adjacent, we are unable to define a modal level and exclude the jobs from the analysis.

2 Some jobs have median levels of education that fall between two categories. In such cases, we require that individuals exceed the median by one level or more to be considered as overqualified.
} 
This should root out any firm-level differences in, for instance, hiring practices. Finally, to account for any geographic differences in hiring practices and recruitment pools within firms we use data on the municipality of employment and define a job as the combination of occupational code, industry, sector, firm, and municipality.

The total number of unique jobs according to these job definitions is slightly lower for the modal than the median and mean approach (see Table 1). At the most detailed level, we operate with more than 653 thousand unique jobs. This level of detail may appear excessive, yet we want to ensure that we compare individuals working in jobs that are as similar as possible. Otherwise, we may run the risk of misinterpreting within-job heterogeneity as representing relative overqualification. If, however, group differences in overqualification are not sensitive to the level of detail in job definitions, this finding has implications for studies investigating relative overqualification in general. Detailed descriptive statistics on the number of people holding "identical" jobs by each method and job definition are provided in the Annex, Table A3.

\subsection{Predicting Overqualification}

To assess differences in relative overqualification, we need to account for differences in age structure between the groups. Since our analyses of relative overqualification are conditioned on access to employment, we also include an analysis of the probability of being employed. We do this by way of simple linear regressions with fixed effects for age and dummies for immigrant groups (with separate groups for first and second-generation immigrants), where the outcome is a dummy indicating whether the individual is employed (Equation 1) or overqualified (Equation 2). Apart from this, we take a parsimonious approach to modeling, for two reasons. First, we want to describe the prevalence of overqualification in a transparent fashion, so we do not wish to clutter our models with control variables. Second, we do not want to run the risk of controlling for intermediate outcomes ("bad controls") which might bias our estimates. Immigrants are less likely to have higher educational levels, such as a PhD or a master's degree, which implies that those who do are more strongly selected within their group than the majority with similar educational levels is. We do however not introduce any group specific weighting procedures, yet in some of our analyses we introduce controls for educational level (see below). Our models are run separately for men and women, for each method (modal, median, and mean), for each job definition, and for different subgroups, such as sectors, where this is relevant. Note that running models separately by subgroups allows the age fixed effects to vary between subgroups. Results presented in graphs are predicted probabilities for 25 -year-olds, with $95 \%$ confidence intervals from robust standard errors.

$$
\begin{gathered}
p(\overline{\text { employed }})_{i}=\alpha+\beta_{1} \times \text { age }_{i}+\beta_{2} \\
\times \text { immigrant background group }_{i} \\
p\left(\text { over qualified }_{i}=\alpha+\beta_{1} \times \text { age }_{i}+\beta_{2}\right. \\
\times \text { immigrant background group }_{i}
\end{gathered}
$$

Note that the method for assessing overqualification and the definition of jobs is not part of the models by way of fixed effects or similar approaches. They are only used to code the outcome variable in Equation 2. We also provide models including information on time since immigration for the immigrant groups. These models are based on Equation 2 but split the indicator dummies for immigrants from each group into three dummies each, indicating a time since immigration of $0-5,6-10$, and 11+ years, respectively. Similarly, we provide models where each immigrant group is split by educational level. In the Annex we also include models controlling for educational level, educational level by field, and reason for immigration (see Tables A5 and A6).

\subsection{Descriptive statistics}

Table 2 shows descriptive statistics for our main sample, when defining a job as the combination of occupation, industry, sector, firm, and municipality, and using the mean approach. For a full table of descriptive statistics for all samples, see the Annex, Table A2. Our sample of people aged 25-64 has a slight majority of women. The mean age is about 44 years. At this detailed job definition, about $7 \%$ of our sample is considered overqualified. Immigrants make up about $12 \%$ of the sample, while descendants of immigrants make up less than a half percent of the total sample. Relative to the total population in the age group, immigrants are underrepresented in our sample, mainly due to lower employment rates. It is worth noting that very few individuals have no edu-

Table 1. Number of unique jobs by job definition and method for assessing overqualification.

\begin{tabular}{lrrr}
\hline Job definition & Abbreviation & Modal & Median and mean \\
\hline Occupation (broad, 4-digit) & Oc. (broad) & 425 & 426 \\
Occupation (narrow, 7-digit) & Oc. & 6638 & 6772 \\
Occupation x Industry & Oc.xIn & 114290 & 118604 \\
Occupation x Industry x Sector & Oc.xIn.xSe. & 128158 & 132830 \\
Occupation x Industry x Sector x Firm & Oc.xIn.xSe.xFi. & 628924 & 641710 \\
Occupation x Industry x Sector x Firm x Municipality & Oc.xIn.xSe.xFi.xMu & 640234 & 653129 \\
\hline
\end{tabular}


Table 2. Descriptive statistics.

\begin{tabular}{|c|c|c|}
\hline & & $\begin{array}{l}\text { Mean approach } \\
\text { OcXInXSeXFiXMu }\end{array}$ \\
\hline Sample size & & 1782867 \\
\hline Women (\%) & & 48,06 \\
\hline Mean age & & 43,82 \\
\hline Public sector employees (\%) & & 34,67 \\
\hline Overqualified (\%) & & 6,89 \\
\hline \multicolumn{3}{|l|}{ Immigrant background (\%) } \\
\hline Norwegian-born majority & & 82,70 \\
\hline Immigrants total & & 12,24 \\
\hline Western Europe (old EU + EFTA) & \multirow{3}{*}{ Western } & 3,10 \\
\hline New EU countries & & 3,05 \\
\hline Canada, USA, Australia and New Zealand & & 0,23 \\
\hline MENA * & \multirow{4}{*}{ Non-western } & 1,45 \\
\hline Asia $++* *$ & & 3,37 \\
\hline Africa, excluding MENA & & 0,60 \\
\hline South and Central America & & 0,44 \\
\hline Second generation total & & 0,46 \\
\hline Western Europe (old EU + EFTA) & \multirow{3}{*}{ Western } & 0,10 \\
\hline New EU countries & & 0,03 \\
\hline Canada, USA, Australia and New Zealand & & 0,01 \\
\hline MENA* & \multirow{4}{*}{ Non-western } & 0,16 \\
\hline Asia $++* *$ & & 0,14 \\
\hline Africa, excluding MENA & & 0,01 \\
\hline South and Central America & & 0,01 \\
\hline Others & & 4,60 \\
\hline \multicolumn{3}{|l|}{ Educational level (\%) } \\
\hline No education, pre-school or missing & & 0,30 \\
\hline Primary & & 0,27 \\
\hline Lower secondary & & 14,56 \\
\hline Upper secondary basic & & 8,10 \\
\hline Upper secondary, final year & & 30,90 \\
\hline Post-secondary, non-tertiary & & 3,85 \\
\hline First stage of tertiary, undergraduate & & 29,52 \\
\hline First stage of tertiary, graduate & & 11,24 \\
\hline Second stage of tertiary, postgraduate & & 1,25 \\
\hline
\end{tabular}

Notes: * Includes Afghanistan, Algeria, Bahrain, Djibouti, Egypt, Iran, Iraq, Israel, Jordan, Kuwait, Lebanon, Libya, Mauritania, Morocco, Oman, Pakistan, Palestine, Qatar, Saudi Arabia, Somalia, Sudan, Syria, Tunisia, United Arab Emirates and Yemen; ** Includes Asia (excluding MENA countries), Eastern European non-EU countries, and Oceania (excluding Australia and New Zealand)

cation, only pre-school education, or missing education, whereas more than $40 \%$ of the sample have tertiary education or higher. Comparing Table 2 with Table A2, we note that the mean approach is the most conservative, providing the lowest levels of overqualification. Descriptive statistics by immigrant background groups are provided in the Annex (Table A4).

\section{Results}

Before we address overqualification, we look at differences in employment for different immigrant and descendant groups, compared to the majority. This analy- sis is carried out in part to provide an overview of the selection into employment, which we condition on in our main analyses. Table 3 contains the results from estimating the probability of being employed (Equation 1) by gender, using linear probability models with age fixed effects. As can be seen, all immigrant groups have a lower probability of being employed than the majority (our reference group) in the reference week. For immigrant men, the difference varies between 3\% (Western Europe) to $29 \%$ (MENA countries). For women, the largest differences are found for immigrants from MENA countries (46\%) and Africa (27\%). For most second-generation descendants, the employment gaps are smaller than for im- 
Table 3. Differences in employment by immigrant background group and gender. OLS with age fixed effects.

\begin{tabular}{|c|c|c|c|c|c|}
\hline & & $\begin{array}{r}\text { Men } \\
\text { Coefficient }\end{array}$ & $P$ & $\begin{array}{r}\text { Women } \\
\text { Coefficient }\end{array}$ & $\mathrm{P}$ \\
\hline \multicolumn{6}{|c|}{ Immigrant group [ref: Norwegian-born majority] } \\
\hline Immigrants & Western Europe (old EU + EFTA) & $-0,0280$ & 0,0000 & $-0,0113$ & 0,0000 \\
\hline Second generation & Western Europe (old EU + EFTA) & $-0,0186$ & 0,0606 & $-0,0456$ & 0,0001 \\
\hline Immigrants & New EU countries & $-0,0878$ & 0,0000 & $-0,1006$ & 0,0000 \\
\hline Second generation & New EU countries & $-0,0562$ & 0,0019 & $-0,0617$ & 0,0019 \\
\hline Immigrants & Canada, USA, Australia, NZ & $-0,0584$ & 0,0000 & $-0,1201$ & 0,0000 \\
\hline Second generation & Canada, USA, Australia, NZ & $-0,0333$ & 0,3957 & $-0,0415$ & 0,3407 \\
\hline Immigrants & MENA & $-0,2929$ & 0,0000 & $-0,4618$ & 0,0000 \\
\hline Second generation & MENA & $-0,1262$ & 0,0000 & $-0,1424$ & 0,0000 \\
\hline Immigrants & Asia & $-0,1291$ & 0,0000 & $-0,1680$ & 0,0000 \\
\hline Second generation & Asia & $-0,0617$ & 0,0000 & $-0,0484$ & 0,0000 \\
\hline Immigrants & Africa, excluding MENA & $-0,2419$ & 0,0000 & $-0,2714$ & 0,0000 \\
\hline Second generation & Africa, excluding MENA & $-0,1184$ & 0,0002 & $-0,0754$ & 0,0222 \\
\hline Immigrants & South and Central America & $-0,1122$ & 0,0000 & $-0,1775$ & 0,0000 \\
\hline Second generation & South and Central America & $-0,1658$ & 0,0000 & $-0,1349$ & 0,0001 \\
\hline Others & & $-0,0375$ & 0,0000 & $-0,0282$ & 0,0000 \\
\hline Constant & & 0,8181 & 0,0000 & 0,7944 & 0,0000 \\
\hline Age FE & & yes & & yes & \\
\hline $\mathrm{R} 2$ & & 0,0519 & & 0,0830 & \\
\hline $\mathrm{N}$ & & 1358362 & & 1296589 & \\
\hline
\end{tabular}

migrants, whereas we find no significant gaps in employment probabilities for descendants from Western Europe (men only) and Canada, USA, Australia, and New Zealand. These findings are in line with earlier studies (Bratsberg, Raaum, \& Røed, 2014, 2018), and may be driven by a number of factors, such as variation in educational systems and the recognition of foreign degrees, cultural distances and language skills, reasons for migration, and the fact that immigrants from many countries have relatively low education.

We now turn to our analysis of overqualification by estimating Equation 2, separately for men and women. In Table 4, we show results for the mean approach applied at the most detailed job definition. As can be seen, all immigrants are more likely to be overqualified than the majority, whereas the differences are not statistically significant for the descendants. These findings are in line with previous studies using less detailed job classifications (E.g., Villund, 2014; Hardoy \& Schøne, 2014).

\subsection{Predicted Overqualification by Method and Job Definition}

In order to assess the sensitivity of our estimates of the prevalence of overqualification to the choice of method (modal, median, and mean) and to assess the impact of our detailed job definition, we estimate 36 models separately-one for each combination of method, job definition, and gender. In order to ease presentation, we categorize immigrants and descendants into western/non-western origin groups. The results are provided in Figure 1. As expected, the more detailed definition of jobs provides the lowest estimates of the overall prevalence of overqualification. We also note, as expected, that the mean approach is more conservative than the modal and median approaches. Yet, all models show the same overall pattern: regardless of job definition and method, ${ }^{3}$ immigrants are consistently more likely to be overqualified than the majority and second-generation descendants. In the following, we use our most conservative estimates of the prevalence of overqualification, namely the mean approach at the most detailed job definition.

\subsection{Differences Between Countries of Origin and Sectors}

To provide a more detailed assessment of overqualification, we divide our sample into 16 groups consisting of immigrants from seven countries/regions of origin, descendants of immigrants from these same groups, Norwegian-born majority, and a heterogeneous group of "others". All analyses are shown separately by gender and public/private sector. We use a strict definition of public sector, implying that government or municipalityowned enterprises are counted in the private sector. Due to more formalized hiring processes and a higher degree of legal requirements in the public sector, we expect a lower prevalence of overqualification in this sector compared to the private sector (Heath \& Yu, 2005). If the sheltering hypothesis in public sector holds, we should

\footnotetext{
${ }_{3}$ This is in line with Hardoy and Schøne (2014), who, using the mean and modal approach, find that the choice of measurement has little impact on the overall results.
} 
Table 4. Differences in overqualification by immigrant background group and gender. Jobs are defined as the combination of occupation, industry, sector, firm and municipality. Overqualification is defined by the mean approach. OLS with age fixed effects.

\begin{tabular}{|c|c|c|c|c|c|}
\hline & & $\begin{array}{r}\text { Men } \\
\text { Coefficient }\end{array}$ & $P$ & $\begin{array}{c}\text { Women } \\
\text { Coefficient }\end{array}$ & $\mathrm{P}$ \\
\hline \multicolumn{6}{|c|}{ Immigrant group [ref: Norwegian-born majority] } \\
\hline Immigrants & Western Europe (old EU + EFTA) & 0,0689 & 0,0000 & 0,0630 & 0,0000 \\
\hline Second generation & Western Europe (old EU + EFTA) & 0,0071 & 0,5117 & 0,0214 & 0,0594 \\
\hline Immigrants & New EU countries & 0,1041 & 0,0000 & 0,1969 & 0,0000 \\
\hline Second generation & New EU countries & 0,0014 & 0,9375 & 0,0223 & 0,2514 \\
\hline Immigrants & Canada, USA, Australia, NZ & 0,1115 & 0,0000 & 0,1439 & 0,0000 \\
\hline Second generation & Canada, USA, Australia, NZ & $-0,0072$ & 0,8226 & 0,0568 & 0,2096 \\
\hline Immigrants & MENA & 0,0651 & 0,0000 & 0,0266 & 0,0000 \\
\hline Second generation & MENA & 0,0037 & 0,6659 & 0,0012 & 0,8916 \\
\hline Immigrants & Asia & 0,0778 & 0,0000 & 0,1138 & 0,0000 \\
\hline Second generation & Asia & 0,0067 & 0,4613 & 0,0172 & 0,0852 \\
\hline Immigrants & Africa, excluding MENA & 0,0984 & 0,0000 & 0,0270 & 0,0000 \\
\hline Second generation & Africa, excluding MENA & 0,0766 & 0,0599 & 0,0656 & 0,0910 \\
\hline Immigrants & South and Central America & 0,1156 & 0,0000 & 0,1311 & 0,0000 \\
\hline Second generation & South and Central America & $-0,0187$ & 0,4900 & $-0,0042$ & 0,8968 \\
\hline Others & & 0,0125 & 0,0000 & 0,0122 & 0,0000 \\
\hline Constant & & 0,0814 & 0,0000 & 0,1004 & 0,0000 \\
\hline Age FE & & yes & & yes & \\
\hline $\mathrm{R} 2$ & 0,0133 & & 0,0300 & & \\
\hline $\mathrm{N}$ & & 704450 & & 693901 & \\
\hline
\end{tabular}
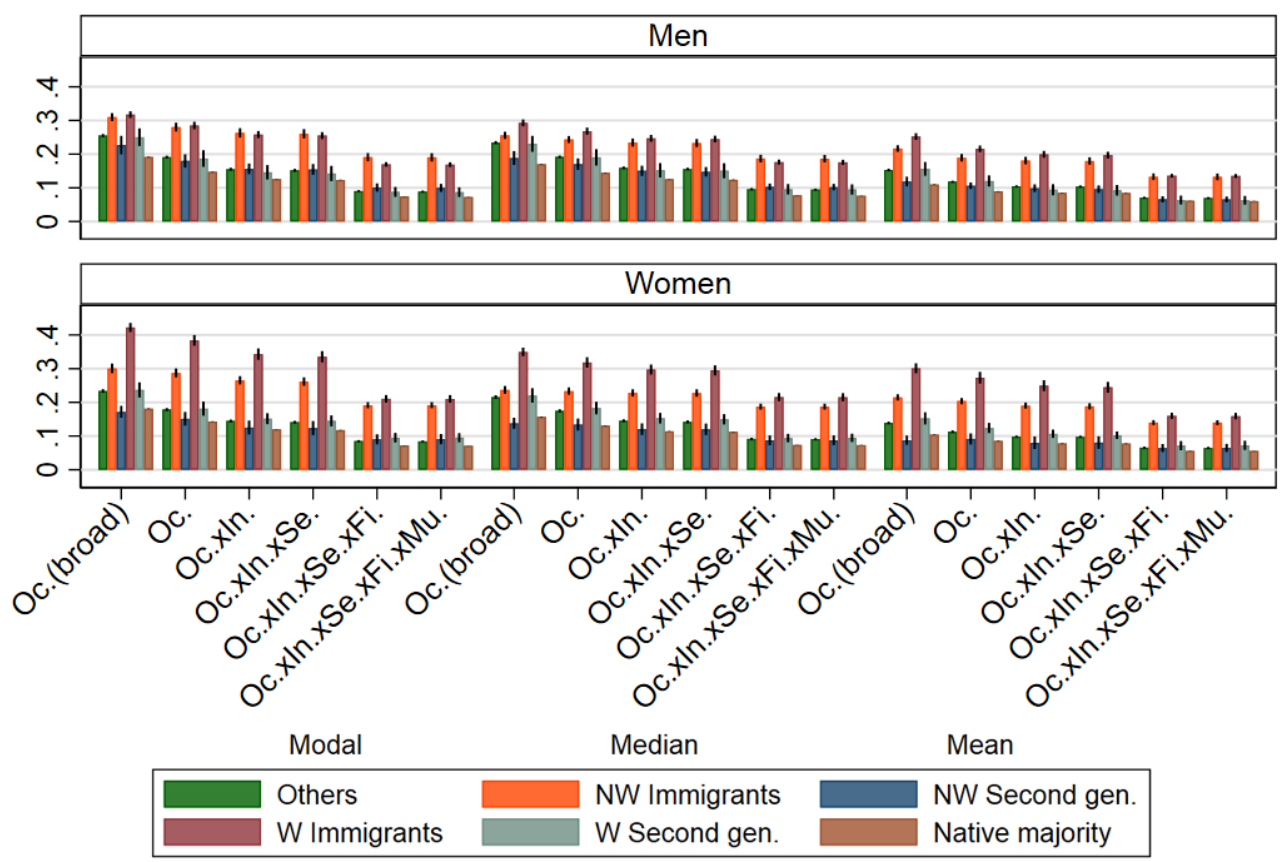

Figure 1. Predicted overqualification among non-western immigrants, non-western second generation, western immigrants, western second generation, others, and the majority. 36 models estimated with age fixed effects. Note: Nonwestern (NW) countries include the country groups MENA, Asia ++ , Africa excluding MENA and South and Central America.

also expect to find smaller gaps in overqualification between the majority and immigrant population in the public sector.

Figure 2 shows results based on the mean approach at the most detailed job definition. Each box in this fig- ure presents results from a separate model, based on equation 2. To ease comparison, a horizontal line represents the predicted values for the majority. Overall, levels of overqualification do not differ dramatically between the majority and second-generation descendants 

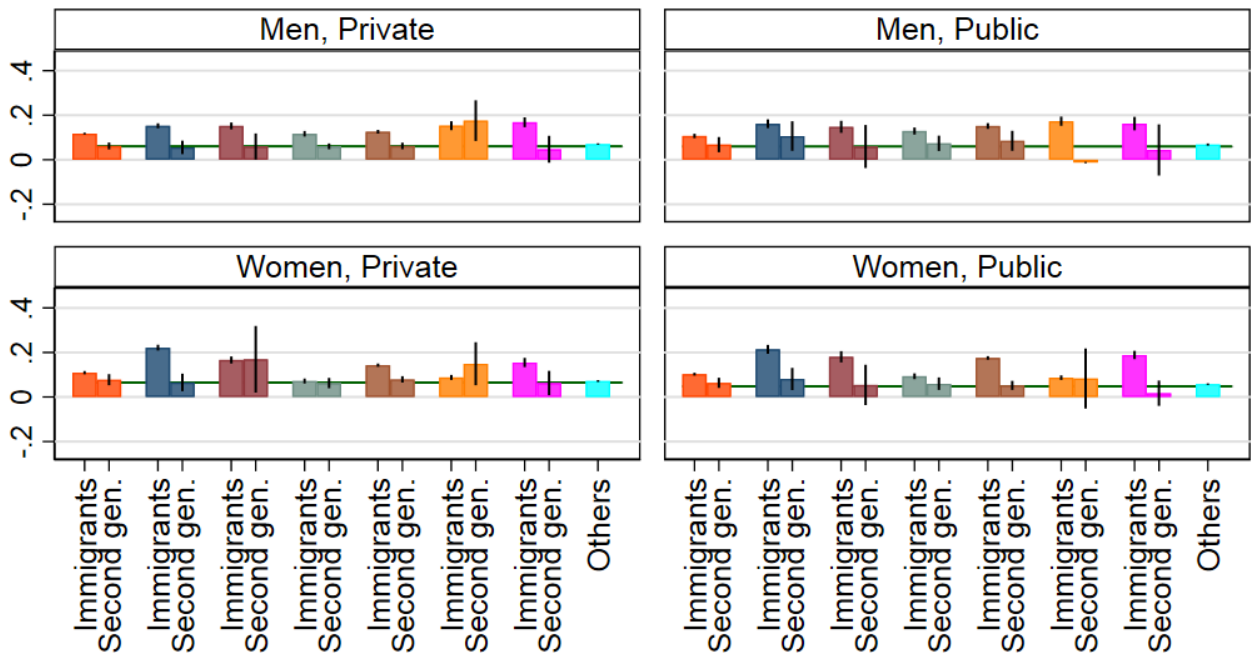

Mean, Oc.xIn.xSe.xFi.xMu.

\begin{tabular}{|l|l|l|}
\hline Native majority & W. Europe & New EU \\
CA,USA,AU,NZ & MENA & Asia + \\
Africa & S. America & Others \\
\hline
\end{tabular}

Figure 2. Predicted overqualification among immigrants and the second generation from seven country-of-origin groups and others, compared to the majority, by sector. Note: 4 models estimated with age fixed effects.

of immigrants and in the cases where such differences are marked, the confidence intervals are wide. However, immigrants from all countries of origin are more likely to be overqualified than the majority in both the public and the private sector. The only exceptions are for women from MENA-countries and Africa. The fact that it is difficult to discern any substantial differences between sectors suggests that when it comes to overqualification, the public sector does not play a sheltering role. The comparatively low prevalence of overqualification among immigrant women from MENA countries and Africa may be related to the relatively low levels of education in these groups, and/or their lower employment rates.

\subsection{Overqualification by Time Since Immigration}

By further subdividing the groups of immigrants by number of years since they immigrated, a clear pattern emerges. Figure 3 displays results for the most detailed job definition by immigrant background, where immigrants are divided into groups by time since their (first) immigration; 0-5, 6-10, and $11+$ years. Overall, employed immigrants who have lived in the country for a shorter time are most likely to be overqualified, and, with a few exceptions, the prevalence of overqualification monotonically falls with time since immigration, nearly closing the gap to the descendants and the majority. Differences between public and private sectors are not large, and the main patterns are roughly similar for men and women. The main finding here is also in line with previous empirical studies in several Western European labor markets (i.e., Nielsen, 2011).

\subsection{Overqualification by Educational Levels}

As discussed above, differences in predicted overqualification between immigrant groups might be related to differences in education. We therefore re-ran the previous models-see Figure 3-with each group subdivided by educational level. We present the results by educational level within each gender and sector group. More precisely, the first and second box of each row displays estimates from the same model, whereas the third and fourth box displays estimates from a second model. Since, by definition, no individuals at the lowest educational level (no schooling, primary or lower secondary schooling, or missing information) can be overqualified, and since very few individuals with only secondary schooling were overqualified, the results for these groups are omitted in the figures (although they are included in the models). Since very few individuals have completed postgraduate education, and we risk identifying individuals in small immigrant groups, the postgraduate group is merged with the graduates (this choice has little impact on the results). Thus, Figure 4 shows results for the two highest educational groups (graduate and postgraduate). Note that the procedure for assigning overqualification to each individual still distinguishes between all educational levels.

As shown in these graphs, immigrants are more often overqualified than the majority at both graduate and postgraduate levels. We also note than the general prevalence of overqualification is higher at the postgraduate level. The gaps are more pronounced for immigrants from the new EU countries in the private sector, and for immigrants from Asia, Africa, and South and Central 

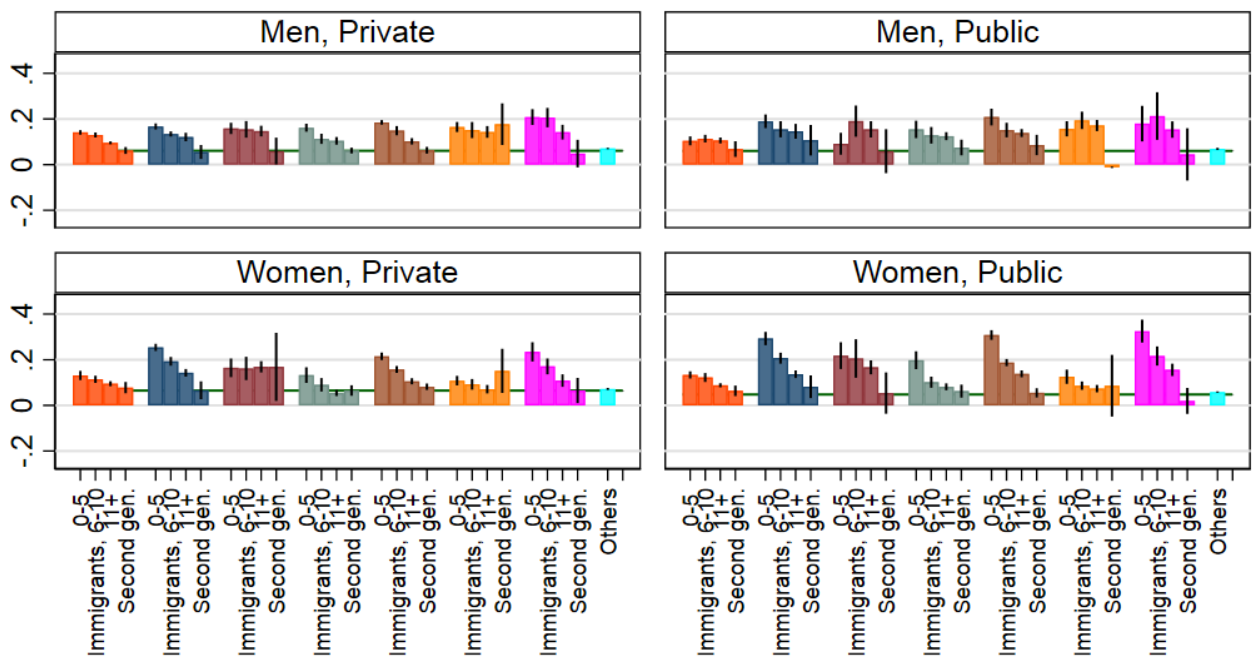

Mean, Oc.xIn.xSe.xFi.xMu.

\begin{tabular}{|l|l|l|}
\hline Native majority & W. Europe & New EU \\
CA,USA,AU,NZ & MENA & Asia + \\
Africa & S. America & Others \\
\hline
\end{tabular}

Figure 3. Predicted overqualification among immigrants, by time since immigration and seven country-of-origin groups, the second generation from seven country-of-origin groups, and others, compared to the majority. Note: 4 models estimated with age fixed effects.

America in the public sector (with high numbers also evident for female graduates from new EU countries). However, it is worth noting the wide confidence intervals for some of the descendant groups, and that the high predicted prevalence of overqualification among male African descendant graduates and postgraduates in the private sector represents a small number of individuals.

\subsection{Robustness Checks and Additional Analyses}

Since we compare individuals within jobs, an individual cannot be overqualified if he or she is the only individual holding that job. This especially becomes an issue when we compare individuals working in the same occupation, industry, sector, firm, and municipality. To test the sensitivity of our approach, we have run the models shown in Figure 2 again, this time excluding all individuals working in jobs with fewer than 10 people. Results from these analyses are included as Annex (Figure A1). The results are roughly similar to those in Figure 2 , implying that this is not a major concern.

Our results may be particularly sensitive to group differences in educational levels and fields of education. Although the aim of this study is to describe, rather than explain group differences in the prevalence of overqualification, an analysis including controls for educational level would be informative regarding such differences among people with similar educational levels. As such, we have included analyses identical to those presented in Tables 3 and 4 and Figures 1, 2 and 3, but with control for educational level ( 5 groups) and educational level $x$ field (286 groups) in the Annex, Tables A5 and A6, Figures A2 to A7. While the figures with educational controls only plot regression coefficients, not predicted values, the overall patterns tell the same story as our main results, though with smaller coefficients: even when comparing people with similar education, overqualification is more common among most immigrant groups, and it falls with time since immigration. The exceptions are immigrants from Western Europe and Canada, USA, Australia and New Zealand when we control for educational level $x$ field. We have also done similar analyses where individuals' stated reason for immigration (work, family, refugee, education, other reasons, a missing category, and a "not relevant" category) are included as control variables (Tables $A 5$ and $A 6$, and Figures $A 8$ to $A 11)$. These analyses produced similar results.

\section{Conclusions}

The main objective of this study has been to provide a thorough, descriptive overview of overqualification among immigrants and their descendants in the Norwegian labor market. The Norwegian welfare state is characterized by relatively high employment protection, which compared to more liberal or conservative welfare states could make it more difficult for immigrants to find jobs, and possibly also more difficult to find relevant jobs, given their qualifications. On the other hand, mismatch in the labor market in terms of overqualification harms firms, individuals and society at large, and these productivity considerations would be similar across most countries. Thus, we would expect that the main trends in this article might be applicable to countries with relatively 

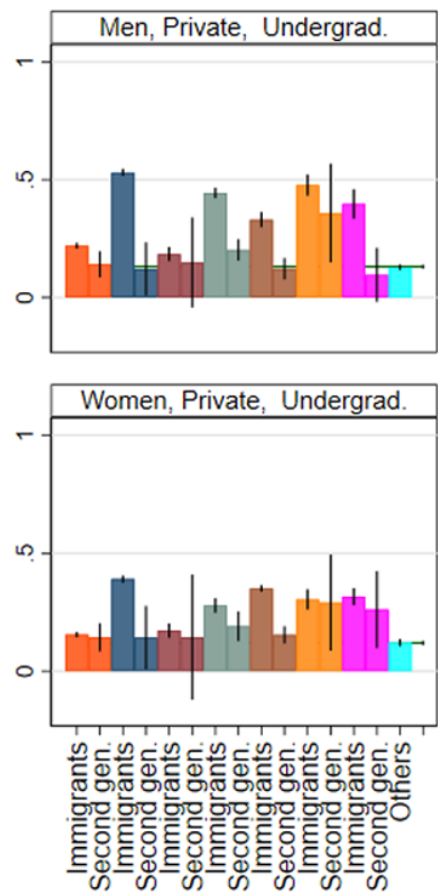
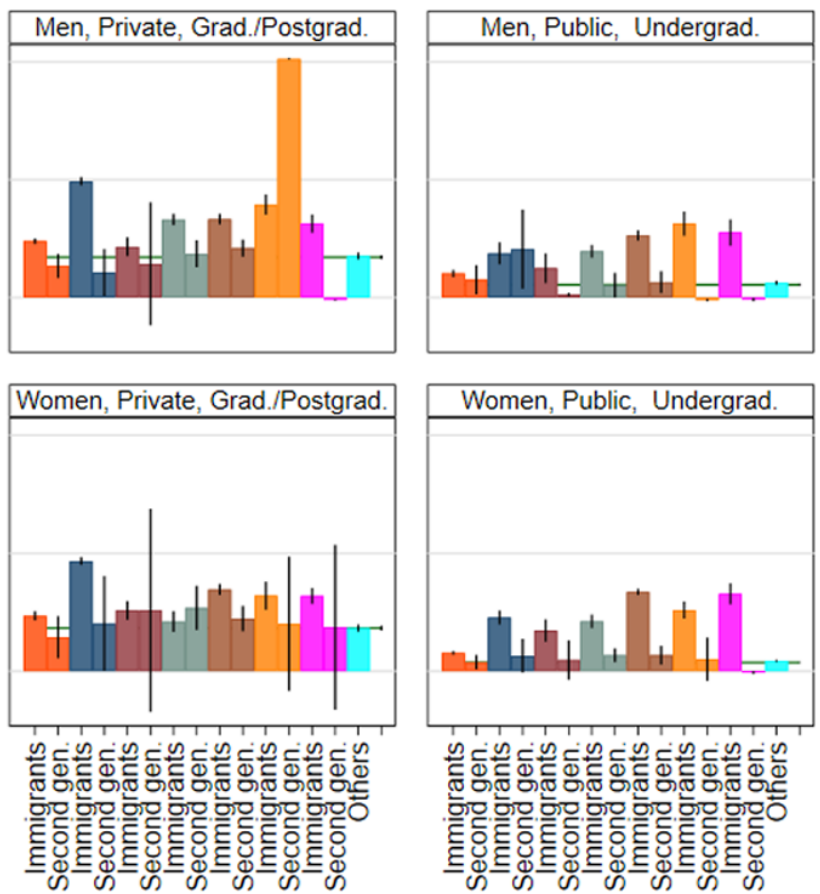
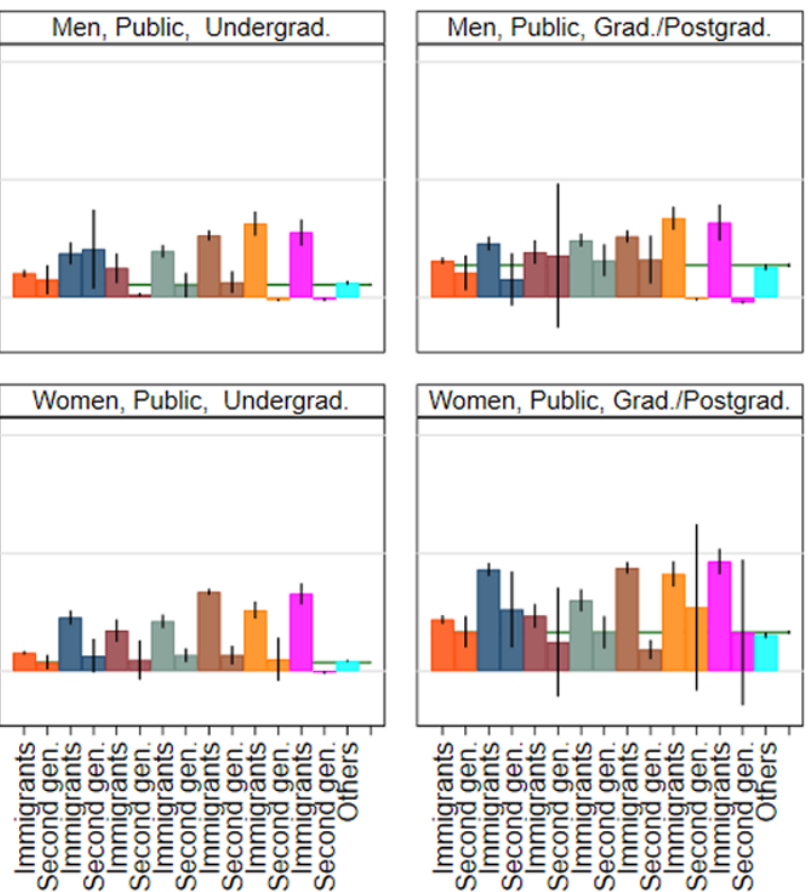

Mean, Oc.xIn.xSe.xFi.xMu.

\begin{tabular}{|l|l|l|}
\hline Native majority & W. Europe & New EU \\
CA,USA,AU,NZ & MENA & Asia + \\
Africa & S. America & Others \\
\hline
\end{tabular}

Figure 4. Predicted overqualification among immigrants and the second generation from seven country-of-origin groups, and others, compared to the majority, by educational level. Note: 4 models estimated with age fixed effects.

strong employment protection and an open and competitive economy.

Our main contributions to the literature can be summarized in three main points. First, we compare three different measurements of relative overqualification, providing an assessment of the impact of the choice of method. Second, by measuring jobs at a more detailed level than in previous research, we address heterogeneity between jobs and compare individuals working in similar jobs. Finally, by differentiating between immigrants and descendants from different countries of origin, we address heterogeneity between immigrant groups in the prevalence of overqualification. Our findings show that, in addition to having lower rates of employment, all immigrant groups are more likely to be overqualified than the Norwegian-born majority. However, second generation descendants of immigrants are not more likely to be overqualified than the majority.

Further, these differences vary little with method for assessing overqualification. We have tested three methods, the mean, modal, and median approach and found the results to be comparable. Group differences in relative overqualification between immigrants and the majority also persist even when using extremely detailed job definitions. In other words, immigrants are more likely to be overqualified compared to the majority, even when comparing individuals in near identical occupational positions.
Relative differences in overqualification do not seem to differ substantially by gender, nor by sector, weakening the hypothesis that the public sector plays a sheltering role. We also found that, while the prevalence of overqualification is generally higher for immigrants than for second-generation descendants and the majority, these differences seem to diminish over time since immigration. This can potentially be explained by differing reasons for migration for different groups, e.g., that migrants that face potential re-migration are more likely to accept jobs below their qualifications. However, it is worth noting that we only use cross-sectional data, so this pattern may be biased by systematic differences between immigrants from the same country origin groups arriving in different periods. For descendants of migrants, the prevalence of overqualification is generally comparable to the level among the majority. We also found that, while overall overqualification is higher among those with higher education, the relative differences between immigrants and the majority are still marked.

In further studies, we aim to dig deeper into the relevant factors in mapping differences in overqualification between minority groups and the majority. Of particular relevance would be to differentiate between pre- and post-immigration qualifications (see Friedberg, 2000). This is in part done by categorizing immigrants by migration recency, but should still be taken into account more precisely, as the (lack of) recognition of foreign edu- 
cation is likely a major hurdle to finding a suitable job for educated immigrants. Using data for multiple years may allow us to explore how initial overqualification might affect the occupational trajectories of immigrants relative to the majority, and to take into account time variation in the composition of the immigrant flow.

\section{Acknowledgements}

This research and this thematic issue have been supported by funding from the European Commission (Grant number H2020 649255). We are grateful for the helpful comments of two anonymous reviewers and the editors.

\section{Conflict of interests}

The authors declare no conflict of interests.

\section{References}

Alba-Ramirez, A. (1993). Mismatch in the Spanish labor market: Overeducation? Journal of Human Resources, 27(2), 259-278.

Barrett, A., Bergin, A., \& Duffy, D. (2006). The labour market characteristics and labour market impacts of immigrants in Ireland. Economic \& Social Review, 37(1), 1-26.

Birkelund, G. E., Chan, T. W., Ugreninov, E., Midtbøen, A. H., \& Rogstad, J. (2018). Do terrorist attacks affect ethnic discrimination in the labour market? Evidence from two randomized field experiments. The British Journal of Sociology. https://doi.org/10.1111/14684446.12344

Birkelund, G. E., Heggeb $\varnothing$, K., \& Rogstad, J. (2017). Additive or multiplicative disadvantage? The scarring effects of unemployment for ethnic minorities. European Sociological Review, 33(1), 17-29.

Bratsberg, B., \& Terrell, D. (2002). School quality and returns to education of U.S. immigrants. Economic Inquiry, 40(2), 177-198.

Bratsberg, B., Raaum, O., \& Røed, K. (2014). Immigrants, labour market performance and social insurance. The Economic Journal, 124(580), F644-F683.

Bratsberg, B., Raaum, O., \& Røed, K. (2018). Job loss and immigrant labour market performance. Economica, 85(337), 124-151.

Brynin, M., \& Longhi, S. (2009). Overqualification: Major or minor mismatch? Economics of Education Review, 28(1), 114-121.

Chiswick, B., \& Miller, P. (2008). Why is the payoff to schooling smaller for immigrants? Labour Economics, 15(6). 1317-1340.

Dolton, P., \& Vignoles, A. (2000). The incidence and effects of overeducation in the UK graduate labour market. Economics of Education Review, 19(2), 179-198.

Duncan, G. J., \& Hoffman, S. D. (1981). The incidence and wage effects of overeducation. Economics of Education Review, 1(1), 75-86.
Duvander, A. Z. E. (2001). Do country-specific skills lead to improved labor market positions? An analysis of unemployment and labor market returns to education among immigrants in Sweden. Work and Occupations, 28(2), 210-233.

Friedberg, R. M. (2000). You can't take it with you? Immigrant assimilation and the portability of human capital. Journal of Labor Economics, 18(2), 221-251.

Green, C., Kler, P., \& Leeves, G. (2007). Immigrant overeducation: Evidence from recent arrivals to Australia. Economics of Education Review, 26(4), 420-432.

Hardoy, I., \& Schøne, P. (2014). Returns to preimmigration education for non-western immigrants: Why so low? Education Economics, 22(1), 48-72.

Hartog, J. (2000). Over-education and earnings: Where are we, where should we go? Economics of Education Review, 19(2), 131-147.

Heath, A., \& Yu, S. (2005). Explaining ethnic minority disadvantage. In A. Heath, J. Ermisch, \& D. Gallie (Eds.), Understanding social change (pp. 187-224). Oxford: Oxford University Press.

Lindley, J. (2009). The over-education of UK immigrants and minority ethnic groups: Evidence from the Labour Force Survey. Economics of Education Review, 28(1), 80-89.

Midtbøen, A. H. (2016). Discrimination of the second generation: Evidence from a field experiment in Norway. Journal of International Migration and Integration, 17(1), 253-272.

Nielsen, C. P. (2011). Immigrant over-education: Evidence from Denmark. Journal of Population Economics, 24(2), 499-520.

OECD. (2013). Discrimination against immigrants: Measurements, incidence and policy instruments. In International Migration Outlook 2013 (pp. 191-230). Paris: OECD Publishing. http://dx.doi.org/10.1787/ migr_outlook-2013-7-en

OECD. (2008). Jobs for immigrants: Labour market integration in Belgium, France, the Netherlands and Portugal (Vol. 2). Paris: OECD Publishing.

Piracha, M., Tani, M., \& Vadean, F. (2012). Immigrant over-and under-education: The role of home country labour market experience. IZA Journal of Migration, 1(1), 3.

Rumberger, R. W. (1987). The impact of surplus schooling on productivity and earnings. Journal of Human Resources, 22(1). 24-50.

Støren, L. A., \& Wiers-Jenssen, J. (2010). Foreign diploma versus immigrant background: Determinants of labor market success or failure? Journal of Studies in International Education, 14(1), 29-49.

Verdugo, R. R., \& Verdugo, N. T. (1989). The impact of surplus schooling on earnings: Some additional findings. Journal of Human Resources, 24(4), 629-643.

Villund, O. (2010). Overkvalifisering blant innvandrere: en registerbasert unders $\varnothing$ kelse for perioden 20072009 (Rapporter 28/2010). Oslo-Kongsvinger: Statistisk sentralbyrå. 
Villund, O. (2014). Overkvalifisering blant innvandrere 2007-2012 (Rapporter 28/2014). Oslo-Kongsvinger: Statistisk sentralbyrå.

Zeng, Z., \& Xie, Y. (2004). Asian-Americans' earnings disadvantage reexamined: The role of place of education. American Journal of Sociology, 109(5), 1075-1108.
Zschirnt, E., \& Ruedin, D. (2016). Ethnic discrimination in hiring decisions: A meta-analysis of correspondence tests 1990-2015. Journal of Ethnic and Migration Studies, 42(7), 1115-1111.

Weiss, A. (1980) Job queues and layoffs in labor markets with flexible wages. Journal of Political Economy, 88(3), 526-538.

\section{About the Authors}

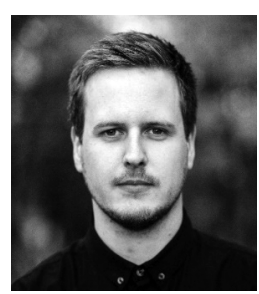

Edvard Nergård Larsen is a PhD candidate in Sociology at the Department of Sociology and Human Geography, University of Oslo. He holds a bachelor's and a master's degree in Sociology from the University of Oslo. His main academic interests lie within the topics of migration, ethnic discrimination, segregation and quantitative methods. His previous work has focused on mechanisms linking individual choice and behavior to aggregate macro-level patterns through agent-based modeling and simulation.

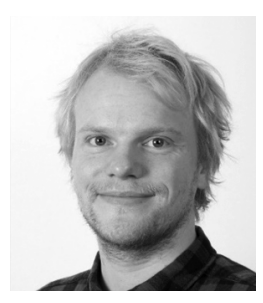

Adrian Farner Rogne is a Sociologist. His research interests are diverse and include social inequalities and social mobility, demography, education, residential segregation, migration, health, mortality, welfare state research, and quantitative methods. Since attaining his master's degree from the University of Oslo, he has worked at Statistics Norway and the Department of Sociology and Human Geography at the University of Oslo.

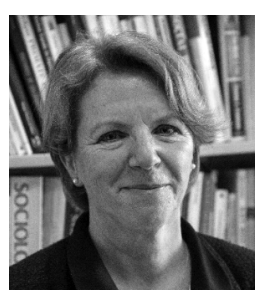

Gunn Elisabeth Birkelund is Professor of Sociology at University of Oslo and a Senior Research Fellow at the Institute of Analytical Sociology, Linköping University. She studied Sociology at the University of Bergen and has had longer research visits at University of Madison-Wisconsin, University of California at Berkeley, University of Oxford and Nuffield College. Her research interests include analytical sociology, labor market studies, social stratification, and social cohesion. She is a Fellow of The European Academy of Sociology, and Fellow of the Norwegian Academy of Science and Letters. 
Annex

Table A1. Coding of educational levels and years of education.

\begin{tabular}{|c|c|c|c|c|c|}
\hline \multicolumn{4}{|c|}{ Original coding of educational levels } & \multicolumn{2}{|c|}{$\begin{array}{l}\text { Recoded educational levels } \\
\text { and years of education }\end{array}$} \\
\hline Level & Level name & $\begin{array}{l}\text { ISCED } \\
2011\end{array}$ & Grade & $\begin{array}{l}\text { Years of } \\
\text { education }\end{array}$ & $\begin{array}{c}\text { Level of } \\
\text { education }\end{array}$ \\
\hline 0 & No education and pre-school education & $01 / 02$ & None & 0 & \\
\hline 1 & Primary education & 1 & 1.-7. & 7 & 1 \\
\hline 2 & Lower secondary education & 2 & $8-10$. & 10 & \\
\hline 3 & Upper secondary education, basic education & $3 / 4$ & 11.-12. & 12 & \\
\hline 4 & Upper secondary, final year & $3 / 4$ & 13. + & 13 & 2 \\
\hline 5 & Post-secondary non-tertiary education & $4 / 5$ & 14. + & 14 & \\
\hline 6 & First stage of tertiary education, undergraduate level & 6 & 14.-17. & 17 & 3 \\
\hline 7 & First stage of tertiary education, graduate level & 7 & 18.-19. & 19 & 4 \\
\hline 8 & Second stage of tertiary education, postgraduate education & 8 & 20. + & 22 & 5 \\
\hline 9 & Unspecified (missing) & & & 0 & 1 \\
\hline . & [missing] & & & 0 & 1 \\
\hline
\end{tabular}




\begin{tabular}{|c|c|c|c|c|c|c|c|c|c|c|c|c|c|c|c|c|c|}
\hline \multicolumn{6}{|c|}{ Modal } & \multicolumn{6}{|c|}{ Median } & \multicolumn{6}{|c|}{ Mean } \\
\hline $\begin{array}{l}\vec{E} \\
\overline{0} \\
\dot{\omega} \\
\dot{0}\end{array}$ & $\dot{0}$ & $\begin{array}{l}\frac{c}{x} \\
\dot{U} \\
0\end{array}$ & 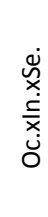 & 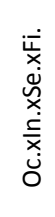 & 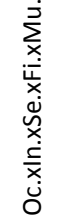 & $\begin{array}{l}\bar{E} \\
\frac{0}{5} \\
\dot{0} \\
\dot{0}\end{array}$ & $\dot{0}$ & $\begin{array}{l}\frac{\bar{c}}{x} \\
\dot{U} \\
\end{array}$ & 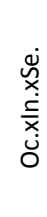 & 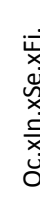 & 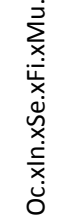 & 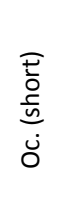 & $\dot{0}$ & 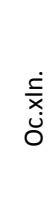 & 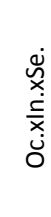 & 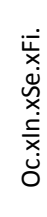 & 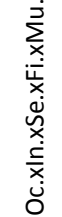 \\
\hline
\end{tabular}

\begin{tabular}{|c|c|c|c|c|c|c|c|c|c|c|c|c|c|c|c|c|c|c|}
\hline Sample size & 1782865 & 1782291 & 1771263 & 1770672 & 1753872 & 1753646 & 1782867 & 1782867 & 1782867 & 1782867 & 1782867 & 1782867 & 1782867 & 1782867 & 1782867 & 1782867 & 1782867 & 1782867 \\
\hline Women (\%) & 48,06 & 48,06 & 48,11 & 48,11 & 48,07 & 48,07 & 48,06 & 48,06 & 48,06 & 48,06 & 48,06 & 48,06 & 48,06 & 48,06 & 48,06 & 48,06 & 48,06 & 48,06 \\
\hline Mean age & 43,82 & 43,82 & 43,82 & 43,82 & 43,85 & 43,85 & 43,82 & 43,82 & 43,82 & 43,82 & 43,82 & 43,82 & 43,82 & 43,82 & 43,82 & 43,82 & 43,82 & 43,82 \\
\hline Public sector employees (\%) & 34,67 & 34,67 & 34,84 & 34,85 & 34,90 & 34,90 & 34,67 & 34,67 & 34,67 & 34,67 & 34,67 & 34,67 & 34,67 & 34,67 & 34,67 & 34,67 & 34,67 & 34,67 \\
\hline Overqualified (\%) & 20,75 & 16,70 & 14,36 & 14,09 & 8,80 & 8,69 & 18,14 & 15,59 & 13,77 & 13,59 & 9,06 & 8,98 & 12,60 & 10,53 & 9,79 & 9,72 & 6,96 & 6,89 \\
\hline \multicolumn{19}{|l|}{ Immigrant background (\%) } \\
\hline Native majority & 82,70 & 82,70 & 82,72 & 82,73 & 82,88 & 82,88 & 82,70 & 82,70 & 82,70 & 82,70 & 82,70 & 82,70 & 82,70 & 82,70 & 82,70 & 82,70 & 82,70 & 82,70 \\
\hline Immigrants total & 12,24 & 12,23 & 12,22 & 12,22 & 12,06 & 12,06 & 12,24 & 12,24 & 12,24 & 12,24 & 12,24 & 12,24 & 12,24 & 12,24 & 12,24 & 12,24 & 12,24 & 12,24 \\
\hline Western Europe (old EU + EFTA) & 3,10 & 3,09 & 3,08 & 3,08 & 3,07 & 3,07 & 3,10 & 3,10 & 3,10 & 3,10 & 3,10 & 3,10 & 3,10 & 3,10 & 3,10 & 3,10 & 3,10 & 3,10 \\
\hline New EU countries & 3,05 & 3,05 & 3,05 & 3,05 & 2,99 & 2,99 & 3,05 & 3,05 & 3,05 & 3,05 & 3,05 & 3,05 & 3,05 & 3,05 & 3,05 & 3,05 & 3,05 & 3,05 \\
\hline Canada, USA, Australia, NZ & 0,23 & 0,23 & 0,23 & 0,23 & 0,23 & 0,23 & 0,23 & 0,23 & 0,23 & 0,23 & 0,23 & 0,23 & 0,23 & 0,23 & 0,23 & 0,23 & 0,23 & 0,23 \\
\hline MENA * & 1,45 & 1,45 & 1,45 & 1,45 & 1,43 & 1,43 & 1,45 & 1,45 & 1,45 & 1,45 & 1,45 & 1,45 & 1,45 & 1,45 & 1,45 & 1,45 & 1,45 & 1,45 \\
\hline Asia $++* *$ & 3,37 & 3,37 & 3,37 & 3,37 & 3,32 & 3,32 & 3,37 & 3,37 & 3,37 & 3,37 & 3,37 & 3,37 & 3,37 & 3,37 & 3,37 & 3,37 & 3,37 & 3,37 \\
\hline Africa, excluding MENA & 0,60 & 0,60 & 0,60 & 0,60 & 0,59 & 0,59 & 0,60 & 0,60 & 0,60 & 0,60 & 0,60 & 0,60 & 0,60 & 0,60 & 0,60 & 0,60 & 0,60 & 0,60 \\
\hline South and Central America & 0,44 & 0,44 & 0,44 & 0,44 & 0,43 & 0,43 & 0,44 & 0,44 & 0,44 & 0,44 & 0,44 & 0,44 & 0,44 & 0,44 & 0,44 & 0,44 & 0,44 & 0,44 \\
\hline Second generation total & 0,46 & 0,46 & 0,46 & 0,46 & 0,46 & 0,46 & 0,46 & 0,46 & 0,46 & 0,46 & 0,46 & 0,46 & 0,46 & 0,46 & 0,46 & 0,46 & 0,46 & 0,46 \\
\hline Western Europe (old EU + EFTA) & 0,10 & 0,10 & 0,10 & 0,10 & 0,10 & 0,10 & 0,10 & 0,10 & 0,10 & 0,10 & 0,10 & 0,10 & 0,10 & 0,10 & 0,10 & 0,10 & 0,10 & 0,10 \\
\hline New EU countries & 0,03 & 0,03 & 0,03 & 0,03 & 0,03 & 0,03 & 0,03 & 0,03 & 0,03 & 0,03 & 0,03 & 0,03 & 0,03 & 0,03 & 0,03 & 0,03 & 0,03 & 0,03 \\
\hline Canada, USA, Australia, NZ & 0,01 & 0,01 & 0,01 & 0,01 & 0,01 & 0,01 & 0,01 & 0,01 & 0,01 & 0,01 & 0,01 & 0,01 & 0,01 & 0,01 & 0,01 & 0,01 & 0,01 & 0,01 \\
\hline MENA* & 0,16 & 0,16 & 0,16 & 0,16 & 0,16 & 0,16 & 0,16 & 0,16 & 0,16 & 0,16 & 0,16 & 0,16 & 0,16 & 0,16 & 0,16 & 0,16 & 0,16 & 0,16 \\
\hline Asia $++* *$ & 0,14 & 0,14 & 0,14 & 0,14 & 0,14 & 0,14 & 0,14 & 0,14 & 0,14 & 0,14 & 0,14 & 0,14 & 0,14 & 0,14 & 0,14 & 0,14 & 0,14 & 0,14 \\
\hline Africa, excluding MENA & 0,01 & 0,01 & 0,01 & 0,01 & 0,01 & 0,01 & 0,01 & 0,01 & 0,01 & 0,01 & 0,01 & 0,01 & 0,01 & 0,01 & 0,01 & 0,01 & 0,01 & 0,01 \\
\hline South and Central America & 0,01 & 0,01 & 0,01 & 0,01 & 0,01 & 0,01 & 0,01 & 0,01 & 0,01 & 0,01 & 0,01 & 0,01 & 0,01 & 0,01 & 0,01 & 0,01 & 0,01 & 0,01 \\
\hline Others & 4,60 & 4,60 & 4,59 & 4,59 & 4,59 & 4,59 & 4,60 & 4,60 & 4,60 & 4,60 & 4,60 & 4,60 & 4,60 & 4,60 & 4,60 & 4,60 & 4,60 & 4,60 \\
\hline \multicolumn{19}{|l|}{ Educational level (\%) } \\
\hline No education, pre-school or missing & 0,30 & 0,30 & 0,29 & 0,29 & 0,29 & 0,29 & 0,30 & 0,30 & 0,30 & 0,30 & 0,30 & 0,30 & 0,30 & 0,30 & 0,30 & 0,30 & 0,30 & 0,30 \\
\hline Primary & 0,27 & 0,27 & 0,27 & 0,27 & 0,27 & 0,27 & 0,27 & 0,27 & 0,27 & 0,27 & 0,27 & 0,27 & 0,27 & 0,27 & 0,27 & 0,27 & 0,27 & 0,27 \\
\hline Lower secondary & 14,56 & 14,56 & 14,53 & 14,52 & 14,39 & 14,39 & 14,56 & 14,56 & 14,56 & 14,56 & 14,56 & 14,56 & 14,56 & 14,56 & 14,56 & 14,56 & 14,56 & 14,56 \\
\hline Upper secondary basic & 8,10 & 8,10 & 8,12 & 8,12 & 8,16 & 8,16 & 8,10 & 8,10 & 8,10 & 8,10 & 8,10 & 8,10 & 8,10 & 8,10 & 8,10 & 8,10 & 8,10 & 8,10 \\
\hline Upper secondary, final year & 30,90 & 30,91 & 30,99 & 30,99 & 31,13 & 31,13 & 30,90 & 30,90 & 30,90 & 30,90 & 30,90 & 30,90 & 30,90 & 30,90 & 30,90 & 30,90 & 30,90 & 30,90 \\
\hline Post-secondary, non-tertiary & 3,85 & 3,85 & 3,85 & 3,85 & 3,86 & 3,86 & 3,85 & 3,85 & 3,85 & 3,85 & 3,85 & 3,85 & 3,85 & 3,85 & 3,85 & 3,85 & 3,85 & 3,85 \\
\hline First stage of tertiary, undergraduate & 29,52 & 29,52 & 29,53 & 29,54 & 29,55 & 29,55 & 29,52 & 29,52 & 29,52 & 29,52 & 29,52 & 29,52 & 29,52 & 29,52 & 29,52 & 29,52 & 29,52 & 29,52 \\
\hline First stage of tertiary, graduate & 11,24 & 11,24 & 11,17 & 11,16 & 11,11 & 11,11 & 11,24 & 11,24 & 11,24 & 11,24 & 11,24 & 11,24 & 11,24 & 11,24 & 11,24 & 11,24 & 11,24 & 11,24 \\
\hline Second stage of tertiary, postgraduate & 1,25 & 1,25 & 1,24 & 1,25 & 1,24 & 1,24 & 1,25 & 1,25 & 1,25 & 1,25 & 1,25 & 1,25 & 1,25 & 1,25 & 1,25 & 1,25 & 1,25 & 1,25 \\
\hline
\end{tabular}

Social Inclusion, 2018, Volume 6, Issue 3, Pages 78-103 
Table A3. Descriptive statistics for jobs.

Number of individuals working in the same job

\begin{tabular}{|c|c|c|c|c|c|c|c|c|c|c|c|c|}
\hline & \multirow{2}{*}{$\begin{array}{r}\text { Number } \\
\text { of unique } \\
\text { jobs }\end{array}$} & \multirow{2}{*}{$\begin{array}{r}\text { Mean } \\
\text { number of } \\
\text { individuals }\end{array}$} & \multirow[b]{2}{*}{$\begin{array}{r}\text { SD } \\
\text { individuals }\end{array}$} & \multicolumn{9}{|c|}{ Percentiles } \\
\hline & & & & 1 & 5 & 10 & 25 & 50 & 75 & 90 & 95 & 99 \\
\hline Oc_short & 426 & 4185.13 & 10168.97 & 1 & 1 & 2 & 86 & 833 & 3932 & 11333 & 17018 & 60723 \\
\hline $\mathrm{Oc}^{-}$ & 6772 & 263.27 & 1392.28 & 1 & 1 & 1 & 4 & 25 & 121 & 451 & 1011 & 3771 \\
\hline OcXIn & 118604 & 15.03 & 203.13 & 1 & 1 & 1 & 1 & 2 & 5 & 17 & 38 & 195 \\
\hline OcXInXSe & 132830 & 13.42 & 178.11 & 1 & 1 & 1 & 1 & 2 & 5 & 15 & 33 & 175 \\
\hline OcXInXSeXFi & 641710 & 2.78 & 9.82 & 1 & 1 & 1 & 1 & 1 & 2 & 5 & 8 & 26 \\
\hline OcXInXSeXFiXMu & 653129 & 2.73 & 8.70 & 1 & 1 & 1 & 1 & 1 & 2 & 5 & 8 & 25 \\
\hline
\end{tabular}

Number of individuals working in the same job, weighted by number of individuals

\begin{tabular}{|c|c|c|c|c|c|c|c|c|c|c|c|c|}
\hline & \multirow{2}{*}{$\begin{array}{r}\text { Number } \\
\text { of unique } \\
\text { jobs }\end{array}$} & \multirow{2}{*}{$\begin{array}{r}\text { Mean } \\
\text { number of } \\
\text { individuals }\end{array}$} & \multirow[b]{2}{*}{$\begin{array}{r}\text { SD } \\
\text { individuals }\end{array}$} & \multicolumn{9}{|c|}{ Percentiles } \\
\hline & & & & 1 & 5 & 10 & 25 & 50 & 75 & 90 & 95 & 99 \\
\hline Oc_short & 426 & 28835.52 & 30698.67 & 476 & 1460 & 2708 & 6984 & 16228 & 38172 & 76224 & 112330 & 112330 \\
\hline Oc & 6772 & 7625.17 & 12345.69 & 19 & 87 & 180 & 587 & 2370 & 8084 & 17544 & 45672 & 45796 \\
\hline OcXIn & 118604 & 2759.99 & 7248.78 & 1 & 3 & 6 & 35 & 256 & 1570 & 7049 & 17130 & 42233 \\
\hline OcXInXSe & 132830 & 2376.84 & 6792.70 & 1 & 2 & 5 & 29 & 214 & 1358 & 5605 & 10433 & 41575 \\
\hline OcXInXSeXFi & 641710 & 37.45 & 133.50 & 1 & 1 & 1 & 2 & 5 & 20 & 68 & 149 & 655 \\
\hline OcXInXSeXFiXMu & 653129 & 30.47 & 95.26 & 1 & 1 & 1 & 2 & 5 & 19 & 62 & 130 & 492 \\
\hline
\end{tabular}


Table A3. (Cont.) Descriptive statistics for jobs.

\section{Modal method}

Number of individuals working in the same job

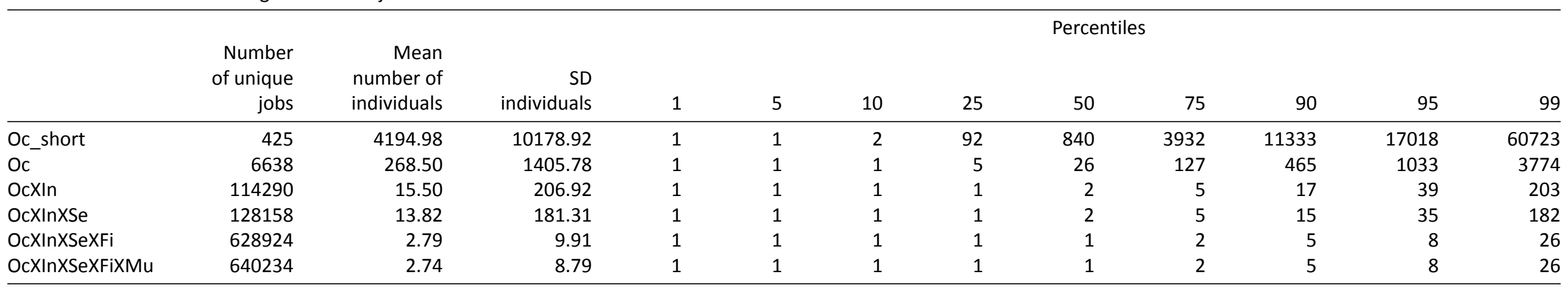

Number of individuals working in the same job, weighted by number of individuals

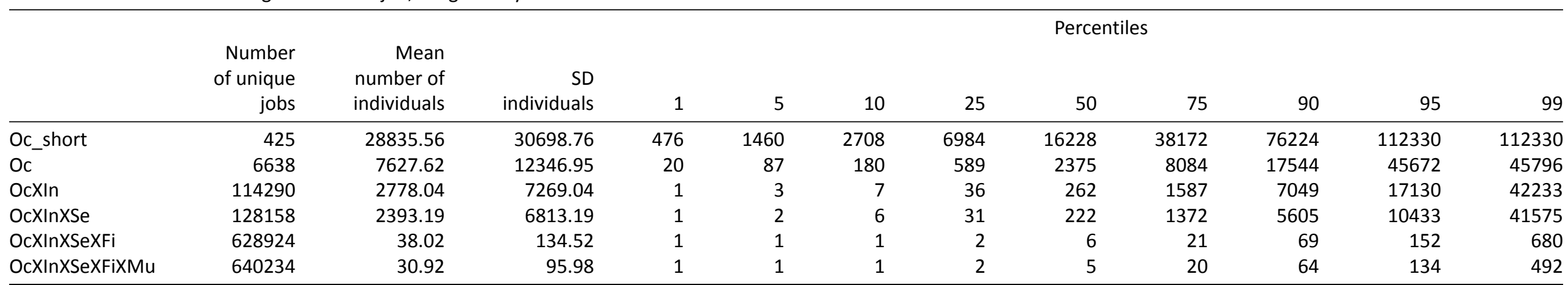

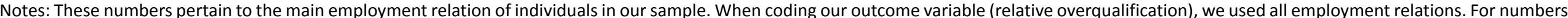

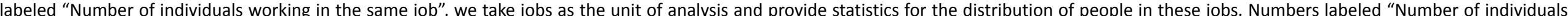

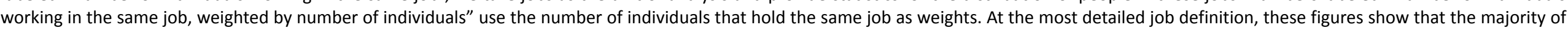
jobs have only one person working in them, but the majority of people work in jobs that are held by more than one person. 
Table A4. Descriptive statistics by immigrant background.

\begin{tabular}{|c|c|c|c|c|c|c|c|c|c|c|c|c|c|c|c|c|}
\hline & & & & 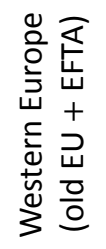 & & 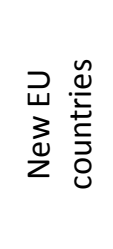 & & 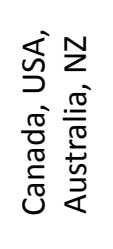 & & $\underset{\sum}{\stackrel{\Sigma}{\Sigma}}$ & & $\begin{array}{l}* \\
* \\
+ \\
+ \\
\frac{\pi}{4} \\
\frac{1}{4}\end{array}$ & & 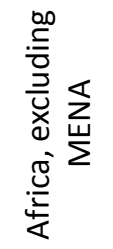 & & 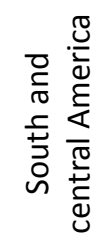 \\
\hline & 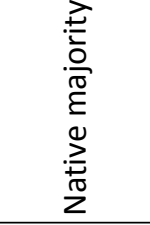 & $\begin{array}{l}\frac{n}{d} \\
\frac{c}{+} \\
0\end{array}$ & 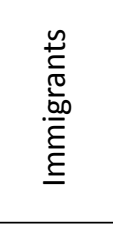 & 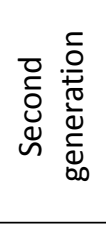 & 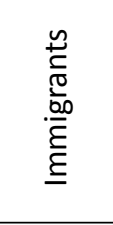 & 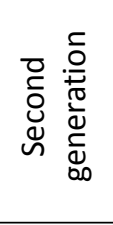 & 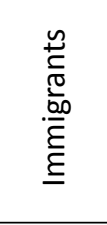 & 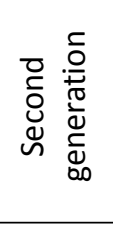 & 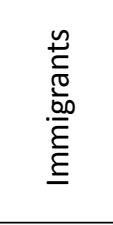 & 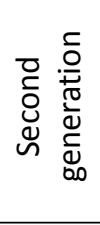 & 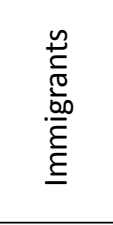 & 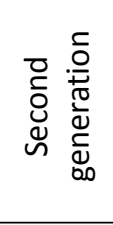 & 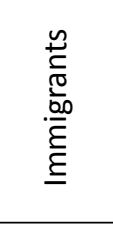 & 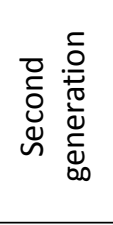 & 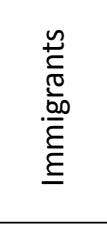 & 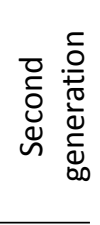 \\
\hline $\mathrm{N}$ & 474443 & 81996 & 55185 & 1770 & 54443 & 616 & 4185 & 141 & 25822 & 2844 & 60037 & 2491 & 10 & 193 & 7838 & 198 \\
\hline Sample \% & 82,70 & 4,60 & 3,10 & 0,10 & 3,05 & 0,03 & 0,23 & 0,01 & 1,45 & 0,16 & 3,37 & 0,14 & 0,60 & 0,01 & 0,44 & 0,01 \\
\hline Mean age & 44,47 & 42,23 & 43,10 & 43,33 & 38,12 & 40,98 & 43,32 & 49,29 & 39,00 & 30,61 & 40,37 & 30,56 & 39,42 & 31,07 & 41,43 & 30,37 \\
\hline \% Women & 48,28 & 48,45 & 44,27 & 46,72 & 38,32 & 48,05 & 44,61 & 46,81 & 35,04 & 47,75 & 59,73 & 48,01 & 45,34 & 50,78 & 56,32 & 48,48 \\
\hline$\%$ Public sector & 35,68 & 34,32 & 30,59 & 31,81 & 13,84 & 29,71 & 28,32 & 43,26 & 30,57 & 31,68 & 34,43 & 27,18 & 42,04 & 32,12 & 34,55 & 25,76 \\
\hline \% Overqualified & 5,73 & 6,98 & 11,28 & 6,72 & 18,71 & 7,14 & 16,13 & 7,09 & 11,32 & 8,12 & 15,21 & 8,63 & 13,30 & 14,51 & 17,30 & 6,57 \\
\hline \multicolumn{17}{|l|}{ Educational level (\%) } \\
\hline No education, pre-school or missing & 0,04 & 0,11 & 1,66 & 0,11 & 0,99 & 0,00 & 1,79 & 0,00 & 4,66 & 0,77 & 2,11 & 0,16 & 3,08 & 0,00 & 2,49 & 0,51 \\
\hline Primary & 0,00 & 0,01 & 0,41 & 0,00 & 0,22 & 0,00 & 0,17 & 0,00 & 5,68 & 0,00 & 4,06 & 0,08 & 4,65 & 0,00 & 1,02 & 0,00 \\
\hline Lower secondary & 14,09 & 12,87 & 11,12 & 14,58 & 12,65 & 17,05 & 5,35 & 11,35 & 31,59 & 25,77 & 22,96 & 18,83 & 29,03 & 18,13 & 18,42 & 26,26 \\
\hline Upper secondary basic & 8,90 & 5,34 & 5,84 & 7,29 & 3,52 & 6,49 & 1,98 & 10,64 & 2,61 & 0,98 & 3,57 & 0,80 & 2,58 & 0,00 & 3,05 & 1,52 \\
\hline Upper secondary, final year & 31,60 & 27,12 & 21,62 & 27,40 & 42,53 & 26,46 & 11,76 & 21,28 & 20,58 & 28,94 & 24,92 & 26,50 & 24,94 & 24,87 & 26,24 & 33,84 \\
\hline Post-secondary, non-tertiary & 4,26 & 3,84 & 0,98 & 3,11 & 0,70 & 4,55 & 1,15 & 3,55 & 1,46 & 2,07 & 1,37 & 2,01 & 1,82 & 1,55 & 1,76 & 2,53 \\
\hline First stage of tertiary, undergraduate & 29,84 & 33,00 & 33,05 & 30,34 & 22,38 & 26,95 & 38,57 & 35,46 & 21,61 & 23,70 & 25,03 & 30,59 & 21,13 & 39,38 & 25,59 & 26,77 \\
\hline First stage of tertiary, graduate & 10,36 & 16,12 & 18,99 & 15,14 & 15,15 & 17,53 & 28,94 & 12,77 & 9,95 & 17,33 & 13,17 & 20,43 & 10,69 & 15,54 & 18,01 & 8,59 \\
\hline Second stage of tertiary, postgraduate & 0,91 & 1,60 & 6,32 & 2,03 & 1,86 & 0,97 & 10,30 & 4,96 & 1,87 & 0,42 & 2,82 & 0,60 & 2,08 & 0,52 & 3,41 & 0,00 \\
\hline
\end{tabular}

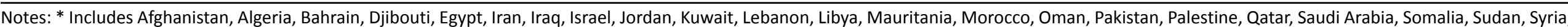

Tunisia, United Arab Emirates, and Yemen; ** Includes Asia (excluding MENA countries), Eastern European non-EU countries, and Oceania (excluding Australia and New Zealand). 

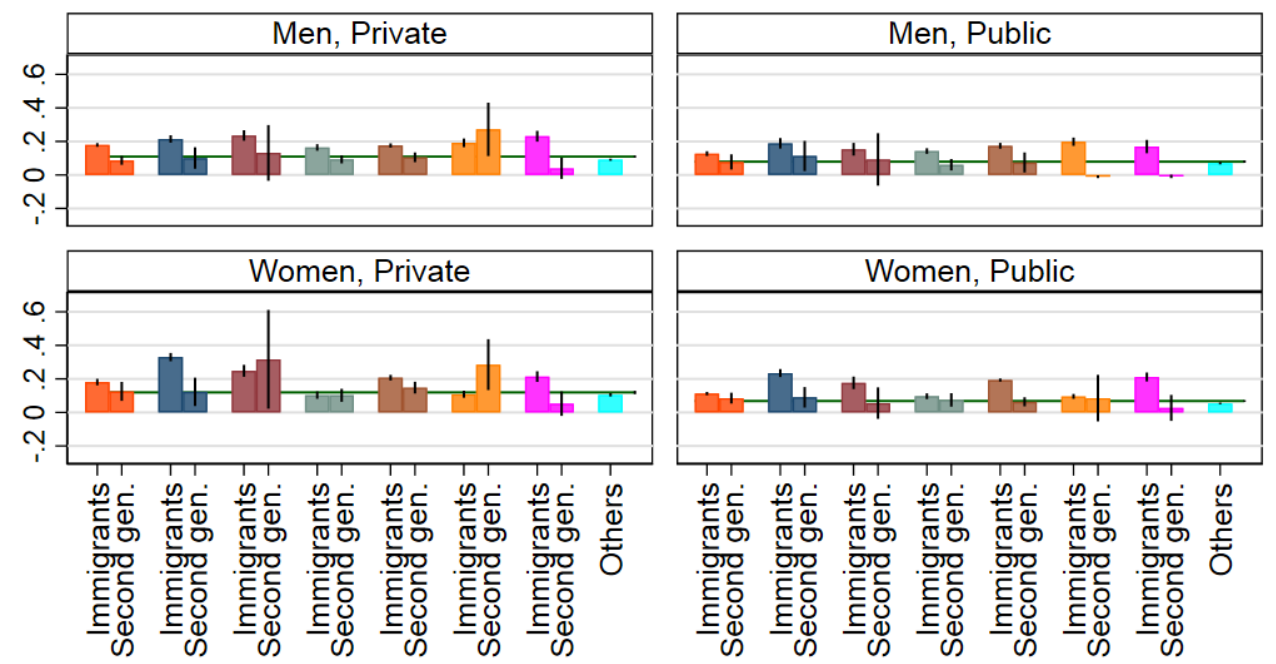

Mean, Oc.xIn.xSe.xFi.xMu., excl. jobs with $<10$ people

\begin{tabular}{|l|l|l|}
\hline Native majority & W. Europe & New EU \\
CA,USA,AU,NZ & MENA & Asia + \\
Africa & S. America & Others \\
\hline
\end{tabular}

Figure A1. Predicted overqualification among immigrants and the second generation from seven countries of origin and others, compared to the native majority. Notes: 4 models estimated with age fixed effects. Excluding jobs shared by less than 10 individuals. 
Table A5. Differences in employment by immigrant background group and gender. OLS with age fixed effects and controls for educational level (5 levels), educational level $x$ field ( 286 groups) and stated reason for immigration (work, family, refugee, education, other reasons, a missing category, and a "not relevant" category).

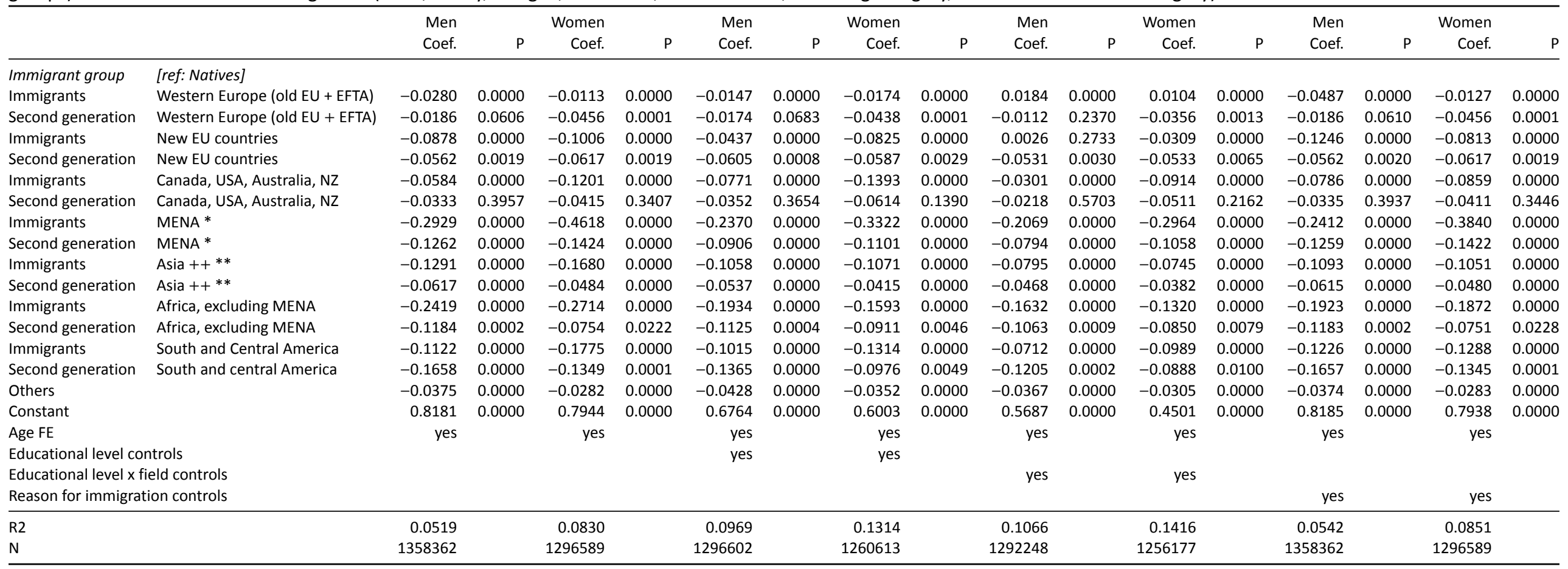


Table A6. Differences in overqualification by immigrant background group and gender. Jobs are defined as the combination of occupation, industry, sector, firm, and municipality. Overqualification is defined by the mean approach. OLS with age fixed effects and controls for educational level (5 levels) educational level $x$ field ( 286 groups) and stated reason for immigration (work, family, refugee, education, other reasons, a missing category, and a "not relevant" category).

\begin{tabular}{|c|c|c|c|c|c|c|c|c|c|c|c|c|c|c|c|c|c|}
\hline & & \multirow{2}{*}{$\begin{array}{l}\text { Men } \\
\text { Coef. }\end{array}$} & \multicolumn{3}{|c|}{ Women } & \multicolumn{2}{|l|}{ Men } & \multicolumn{2}{|l|}{ Women } & \multicolumn{2}{|l|}{ Men } & \multicolumn{2}{|l|}{ Women } & \multirow{2}{*}{$\begin{array}{l}\text { Men } \\
\text { Coef. }\end{array}$} & \multicolumn{3}{|c|}{ Women } \\
\hline & & & $P$ & Coef. & $P$ & Coef. & $P$ & Coef. & $P$ & Coef. & $P$ & Coef. & $P$ & & $\mathrm{P}$ & Coef. & $\mathrm{P}$ \\
\hline mmigrant group & [ref: Natives] & & & & & & & & & & & & & & & & \\
\hline Immigrants & Western Europe (old EU + EFTA) & 0,0689 & 0,0000 & 0,0630 & 0,0000 & 0,0277 & 0,0000 & 0,0283 & 0,0000 & $-0,0056$ & 0,0155 & $-0,0182$ & 0,0000 & 0,0450 & 0,0000 & 0,0454 & 0,0000 \\
\hline Second generation & Western Europe (old EU + EFTA) & 0,0071 & 0,5117 & 0,0214 & 0,0594 & $-0,0104$ & 0,3270 & 0,0101 & 0,3611 & $-0,0128$ & 0,2188 & 0,0033 & 0,7603 & 0,0072 & 0,5072 & 0,0215 & 0,0583 \\
\hline Immigrants & New EU countries & 0,1041 & 0,0000 & 0,1969 & 0,0000 & 0,1155 & 0,0000 & 0,1820 & 0,0000 & 0,1142 & 0,0000 & 0,1043 & 0,0000 & 0,0506 & 0,0000 & 0,1395 & 0,0000 \\
\hline Second generation & New EU countries & 0,0014 & 0,9375 & 0,0223 & 0,2514 & $-0,0114$ & 0,4971 & 0,0178 & 0,3223 & $-0,0176$ & 0,2804 & 0,0072 & 0,6634 & 0,0016 & 0,9286 & 0,0227 & 0,2443 \\
\hline Immigrants & Canada, USA, Australia, NZ & 0,1115 & 0,0000 & 0,1439 & 0,0000 & 0,0250 & 0,0052 & 0,0738 & 0,0000 & $-0,0516$ & 0,0000 & $-0,0355$ & 0,0008 & 0,0739 & 0,0000 & 0,1031 & 0,0000 \\
\hline Second generation & Canada, USA, Australia, NZ & $-0,0072$ & 0,8226 & 0,0568 & 0,2096 & $-0,0334$ & 0,2476 & 0,0141 & 0,7557 & $-0,0342$ & 0,1888 & $-0,0003$ & 0,9954 & $-0,0075$ & 0,8149 & 0,0565 & 0,2114 \\
\hline Immigrants & MENA * & 0,0651 & 0,0000 & 0,0266 & 0,0000 & 0,0805 & 0,0000 & 0,0581 & 0,0000 & 0,0623 & 0,0000 & 0,0393 & 0,0000 & 0,0454 & 0,0000 & 0,0074 & 0,0914 \\
\hline Second generation & MENA * & 0,0037 & 0,6659 & 0,0012 & 0,8916 & 0,0081 & 0,3101 & 0,0114 & 0,1621 & 0,0169 & 0,0334 & 0,0144 & 0,0673 & 0,0044 & 0,6002 & 0,0023 & 0,7831 \\
\hline Immigrants & Asia $++* *$ & 0,0778 & 0,0000 & 0,1138 & 0,0000 & 0,0733 & 0,0000 & 0,1252 & 0,0000 & 0,0511 & 0,0000 & 0,0825 & 0,0000 & 0,0517 & 0,0000 & 0,0783 & 0,0000 \\
\hline Second generation & Asia $++* *$ & 0,0067 & 0,4613 & 0,0172 & 0,0852 & $-0,0053$ & 0,5361 & 0,0133 & 0,1713 & $-0,0005$ & 0,9489 & 0,0190 & 0,0395 & 0,0075 & 0,4127 & 0,0183 & 0,0666 \\
\hline Immigrants & Africa, excluding MENA & 0,0984 & 0,0000 & 0,0270 & 0,0000 & 0,1029 & 0,0000 & 0,0646 & 0,0000 & 0,0780 & 0,0000 & 0,0453 & 0,0000 & 0,0724 & 0,0000 & 0,0077 & 0,1769 \\
\hline Second generation & Africa, excluding MENA & 0,0766 & 0,0599 & 0,0656 & 0,0910 & 0,0722 & 0,0600 & 0,0513 & 0,1699 & 0,0809 & 0,0223 & 0,0247 & 0,4843 & 0,0774 & 0,0576 & 0,0667 & 0,0860 \\
\hline Immigrants & I America & 0,1156 & 0,0000 & 0,1311 & 0,0000 & 0,0963 & 0,0000 & 0,1280 & 0,0000 & 0,0579 & 0,0000 & 0,0678 & 0,0000 & 0,0925 & 0,0000 & 0,0969 & 0,0000 \\
\hline Second generation & South and Central America & $-0,0187$ & 0,4900 & $-0,0042$ & 0,8968 & 0,0081 & 0,7701 & 0,0146 & 0,6361 & 0,0077 & 0,7834 & $-0,0103$ & 0,7082 & $-0,0181$ & 0,5047 & $-0,0032$ & 0,9205 \\
\hline Others & & 0,0125 & 0,0000 & 0,0122 & 0,0000 & $-0,0054$ & 0,0007 & $-0,0009$ & 0,5552 & $-0,0058$ & 0,0003 & $-0,0058$ & 0,0001 & 0,0127 & 0,0000 & 0,0123 & 0,0000 \\
\hline Constant & & 0,0814 & 0,0000 & 0,1004 & 0,0000 & 0,0017 & 0,4068 & 0,0099 & 0,0000 & $-0,0357$ & 0,0000 & $-0,0229$ & 0,0000 & 0,0810 & 0,0000 & 0,0997 & 0,0000 \\
\hline Age FE & & yes & & yes & & yes & & yes & & yes & & yes & & yes & & yes & \\
\hline Educatic & itrols & & & & & yes & & yes & & & & & & & & & \\
\hline Educational level $x \mathrm{fi}$ & eld control & & & & & & & & & yes & & yes & & & & & \\
\hline Reason for immigrat & ion controls & & & & & & & & & & & & & yes & & yes & \\
\hline R2 & & כ & & & & 83 & & 929 & & 0,1546 & & 0,1778 & & 0,0141 & & 0,0315 & \\
\hline $\mathrm{N}$ & & 704450 & & 693901 & & 704450 & & 693901 & & 703308 & & 692704 & & 704450 & & 693901 & \\
\hline
\end{tabular}



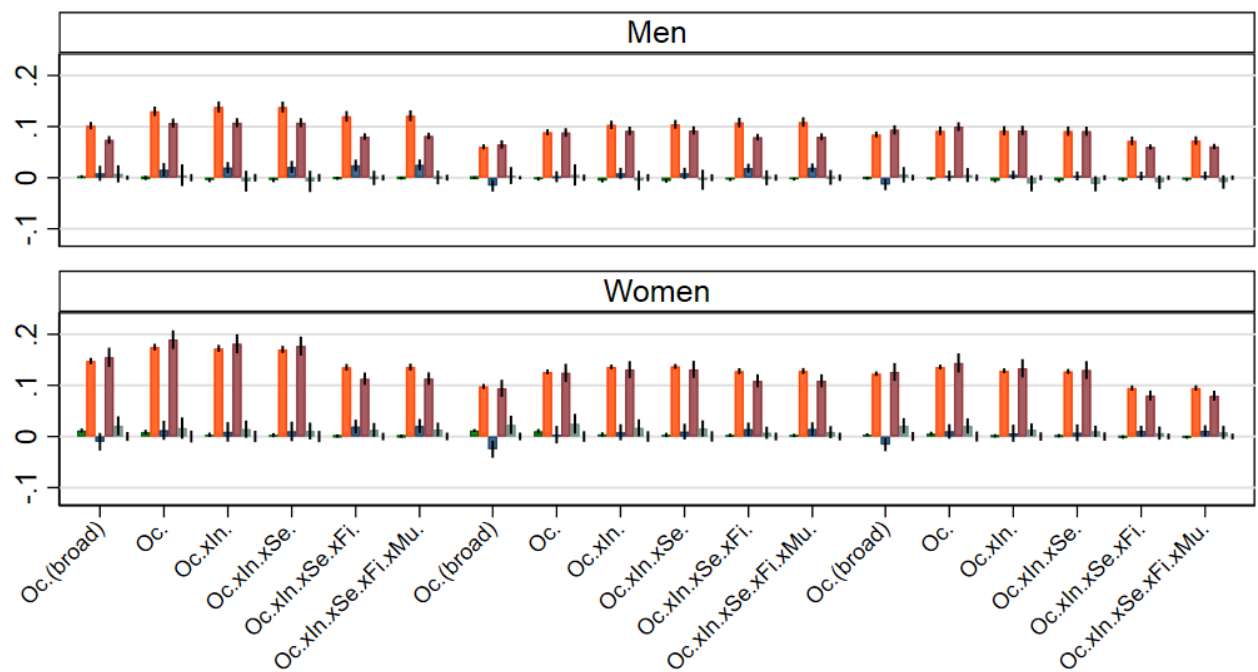

\begin{tabular}{|c|c|c|}
\hline Modal & Median & Mean \\
\hline Others & NW Immigrants & NW Second gen. \\
\hline W Immigrants & W Second gen. & Native majority \\
\hline
\end{tabular}

Figure A2. Differences in overqualification between non-western immigrants, non-western second generation, western immigrants, western second generation, others, and the native majority. 36 models estimated with age fixed effects and controls for educational level (5 levels). Note: Non-western (NW) countries include the country groups MENA, Asia ++, Africa excluding MENA and South and Central America.
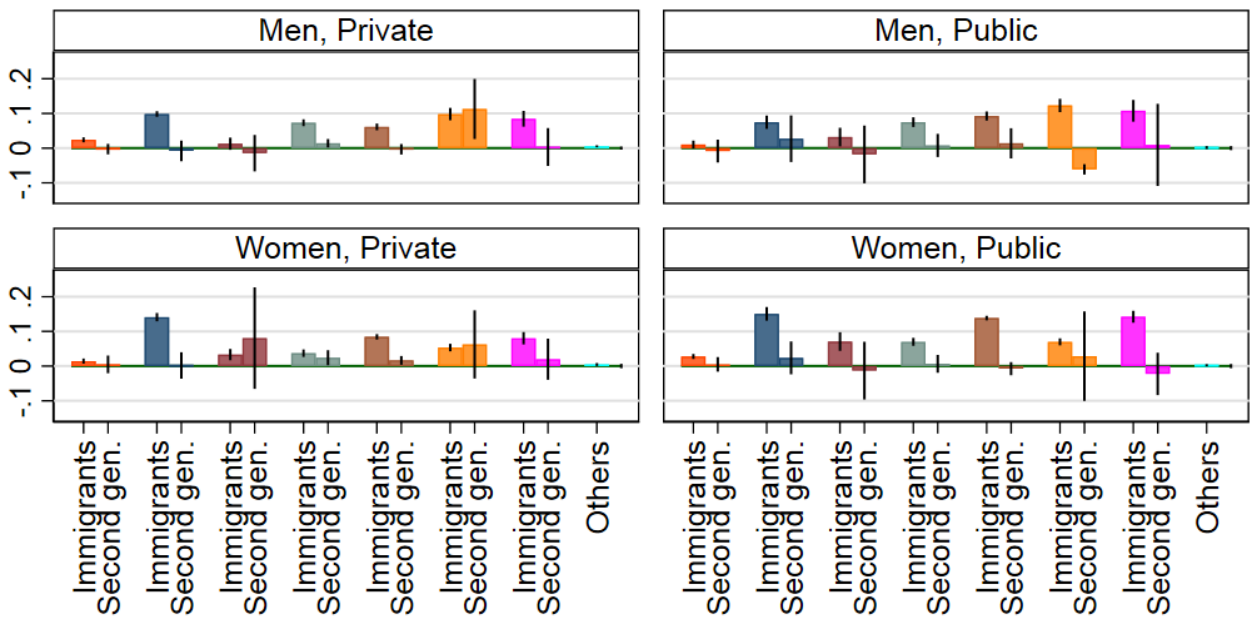

Mean, Oc.xIn.xSe.xFi.xMu.

\begin{tabular}{|l|l|l|}
\hline & W. Europe & New EU \\
\hline Native majority & MENA & Asia + \\
CA,USA,AU,NZ & S. America & Others \\
Africa & S.c
\end{tabular}

Coefficients. Control for educational level

Figure A3. Differences in overqualification between immigrants and the second generation from seven country-of-origin groups, others, and the native majority by sector. Notes: 4 models estimated with age fixed effects and controls for educational level (5 levels). 

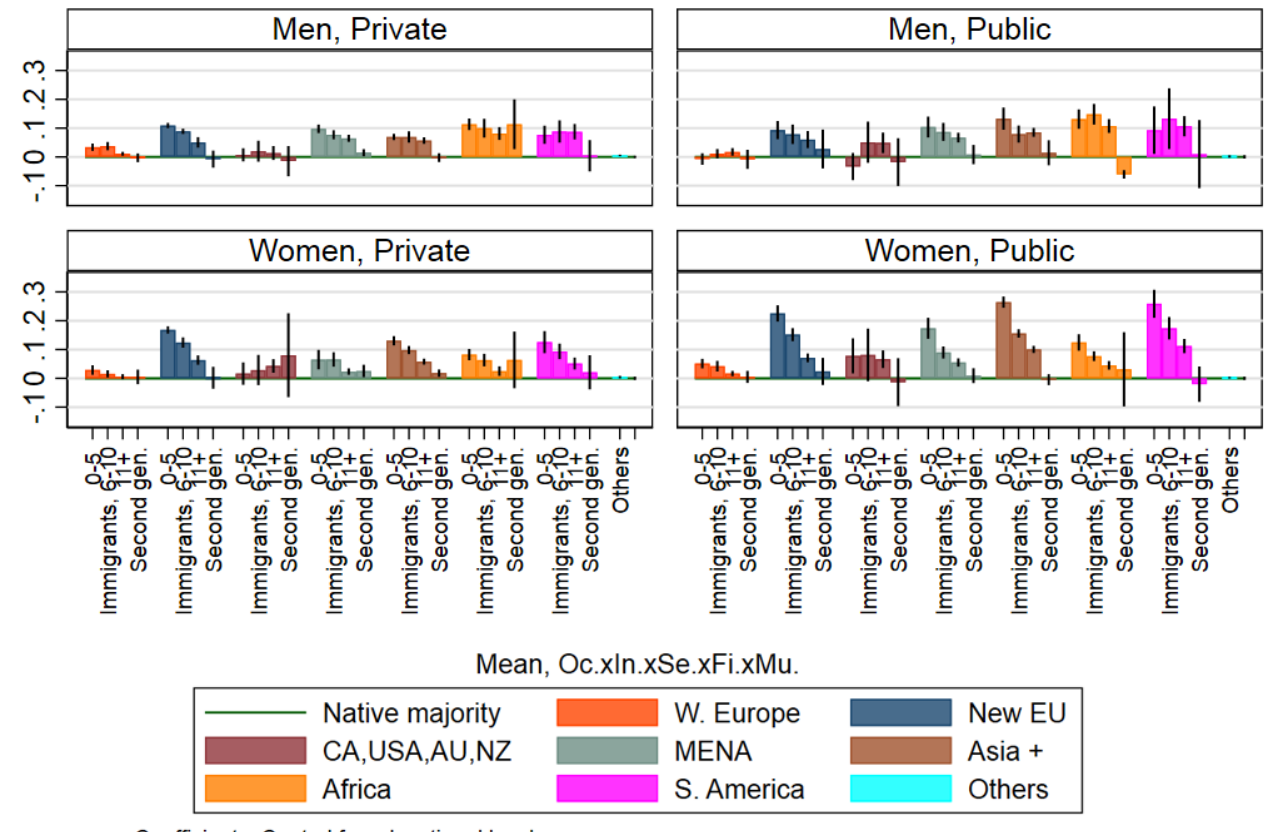

Figure A4. Differences in overqualification between immigrants, by time since immigration and seven country-of-origin groups, the second generation from seven country-of-origin groups, others, and the native majority. Note: 4 models estimated with age fixed and controls for educational level (5 levels).

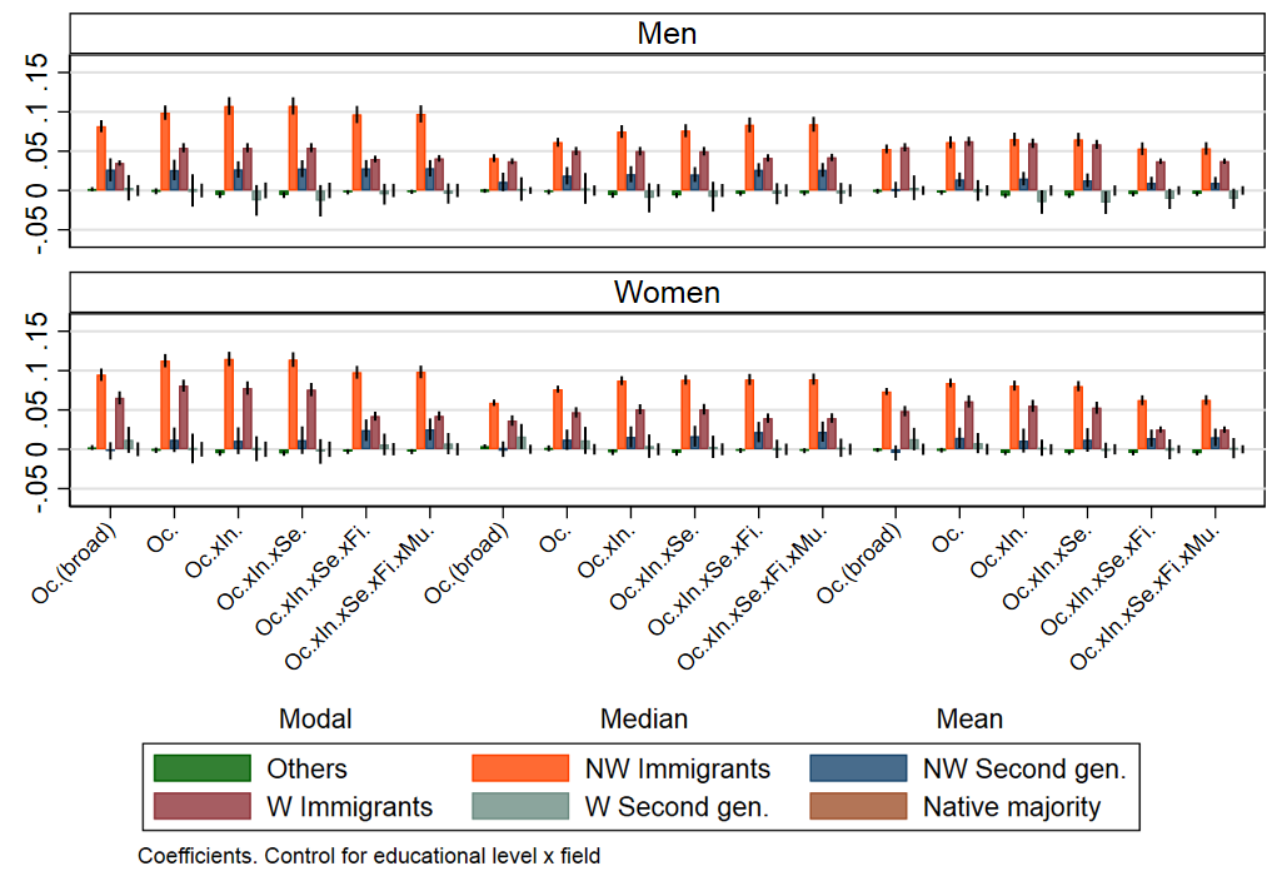

Figure A5. Differences in overqualification between non-western immigrants, non-western second generation, western immigrants, western second generation, others and the native majority. 36 models estimated with age fixed effects and controls for educational level x field (286 groups). Note: Non-western (NW) countries include the country groups MENA, Asia ++ , Africa excluding MENA and South and Central America. 

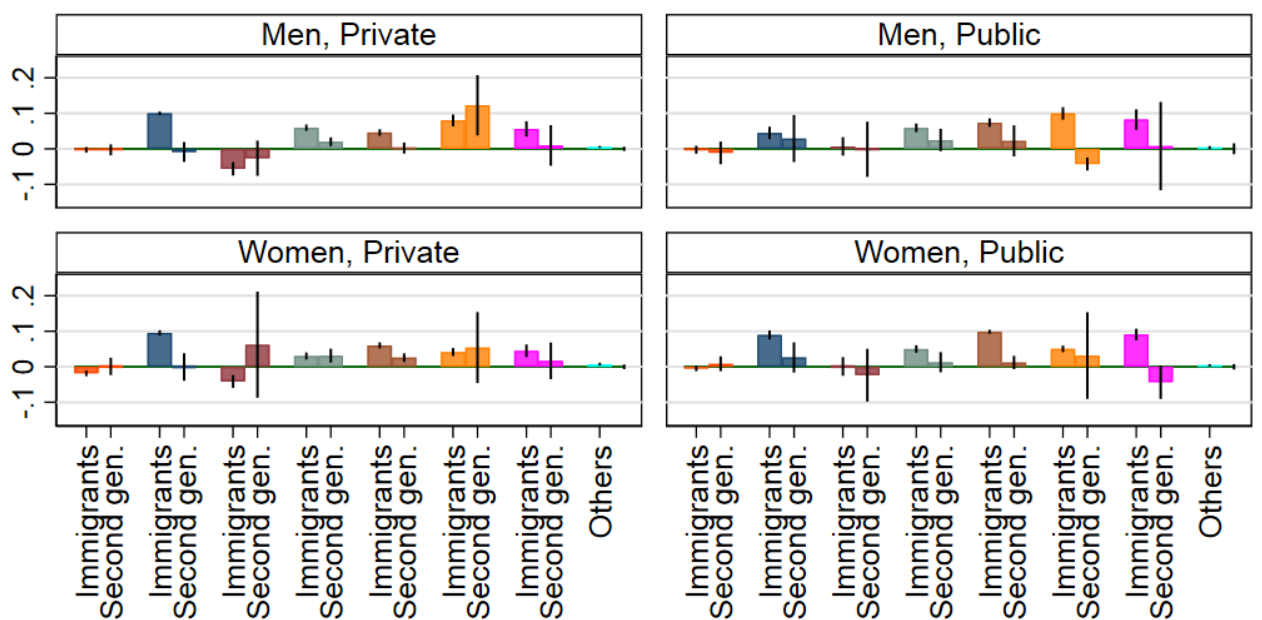

Mean, Oc.xIn.xSe.xFi.xMu.

\begin{tabular}{|l|l|l|}
\hline Native majority & W. Europe & New EU \\
CA,USA,AU,NZ & MENA & Asia + \\
Africa & S. America & Others \\
\hline
\end{tabular}

Coefficients. Control for educational level $x$ field

Figure A6. Differences in overqualification between immigrants and the second generation from seven country-of-origin groups, others, and the native majority by sector. Note: 4 models estimated with age fixed effects and controls for educational level $x$ field (286 groups).
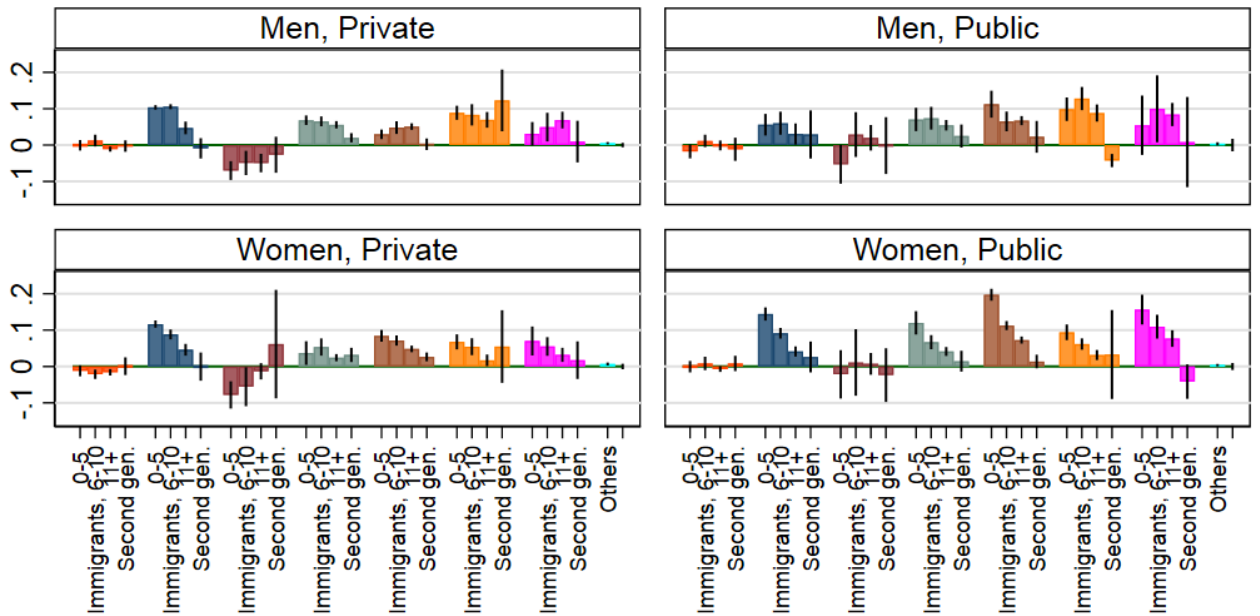

Mean, Oc.xIn.xSe.xFi.xMu

\begin{tabular}{|l|l|l|}
\hline Native majority & W. Europe & New EU \\
CA,USA,AU,NZ & MENA & Asia + \\
Africa & S. America & Others \\
\hline
\end{tabular}

Coefficients. Control for educational level $x$ field

Figure A7. Differences in overqualification between immigrants, by time since immigration and seven country-of-origin groups, the second generation from seven country-of-origin groups, others, and the native majority. Note: 4 models estimated with age fixed effects and controls for educational level $x$ field (286 groups). 


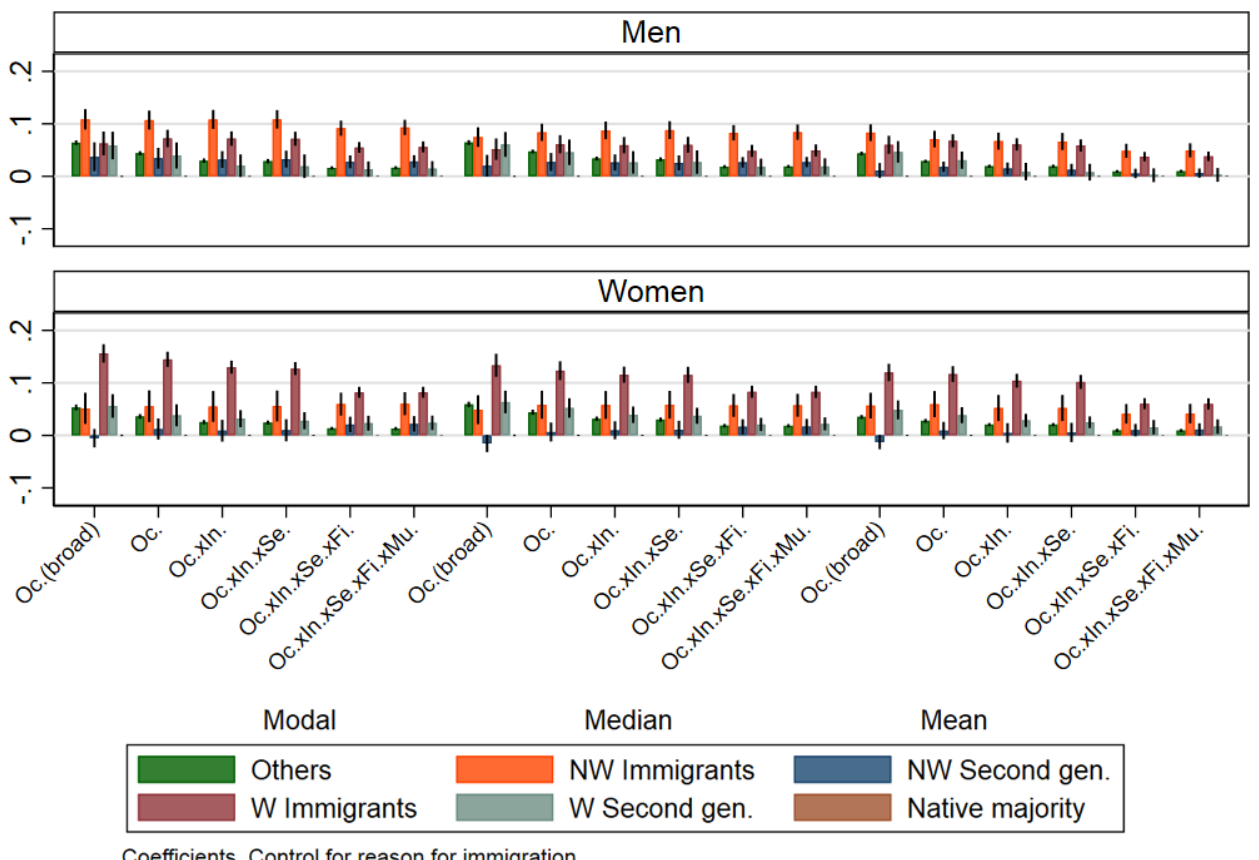

Figure A8. Differences in overqualification between non-western immigrants, non-western second generation, western immigrants, western second generation, others, and the native majority. 36 models estimated with age fixed effects and controls for stated reason for immigration (work, family, refugee, education, other reasons, a missing category, and a "not relevant" category). Note: Non-western (NW) countries include the country groups MENA, Asia ++, Africa excluding MENA and South and Central America.
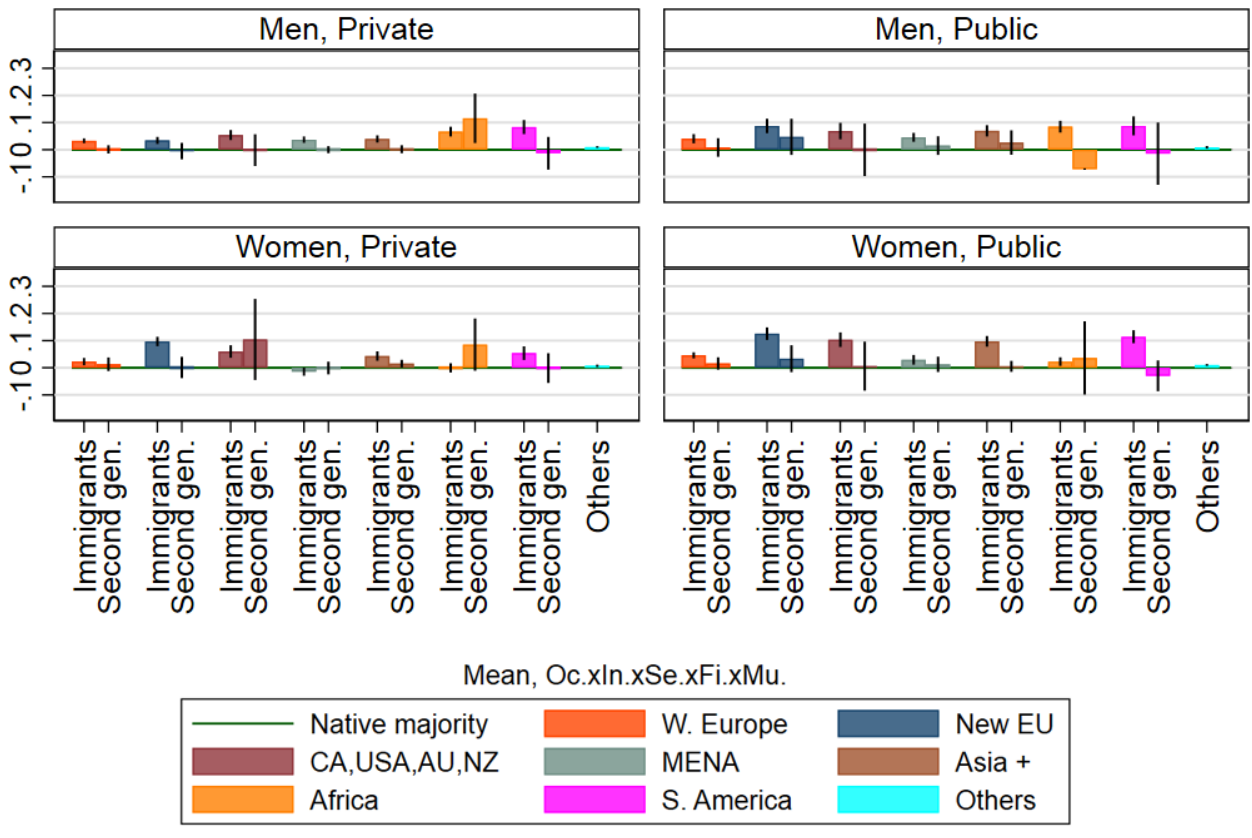

Coefficients. Control for reason for immigration

Figure A9. Differences in overqualification between immigrants and the second generation from seven country-of-origin groups, others, and the native majority by sector. Note: 4 models estimated with age fixed effects and controls for stated reason for immigration (work, family, refugee, education, other reasons, a missing category, and a "not relevant" category). 

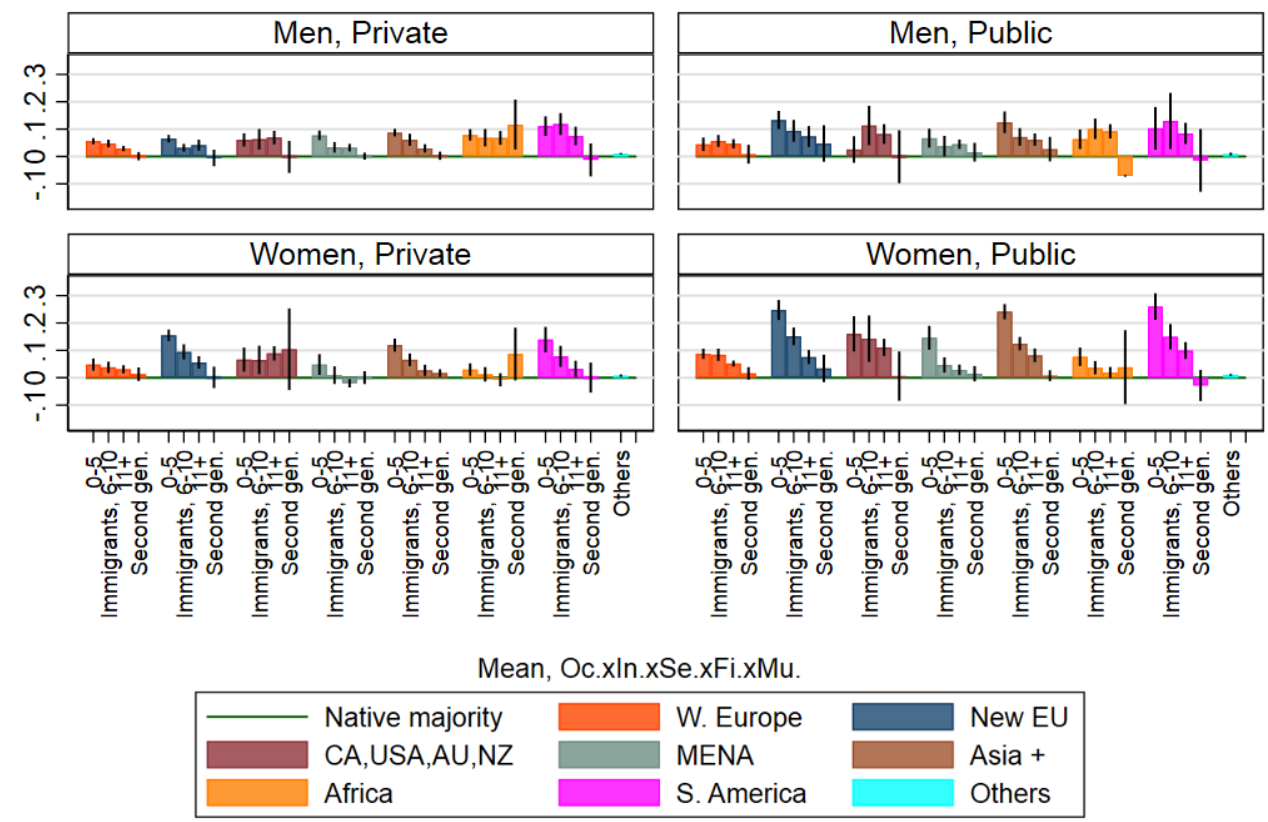

Coefficients. Control for reason for immigration

Figure A10. Differences in overqualification between immigrants, by time since immigration and seven country-of-origin groups, the second generation from seven country of origin groups, others, and the native majority. Note: 4 models estimated with age fixed effects and controls for stated reason for immigration (work, family, refugee, education, other reasons, a missing category, and a "not relevant" category).
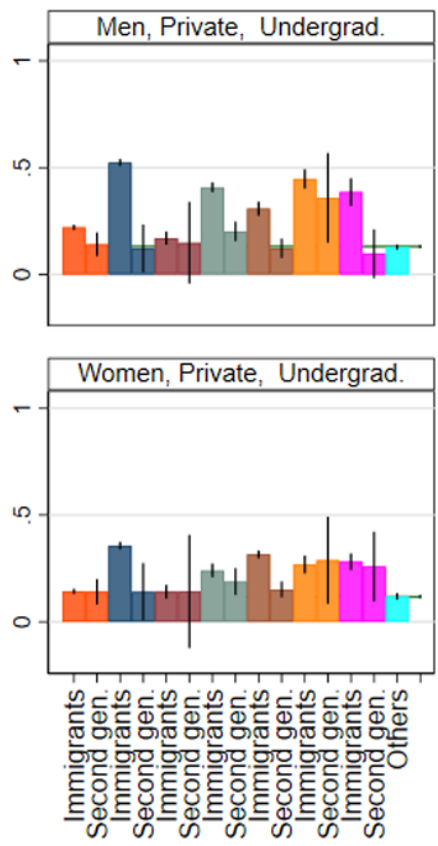
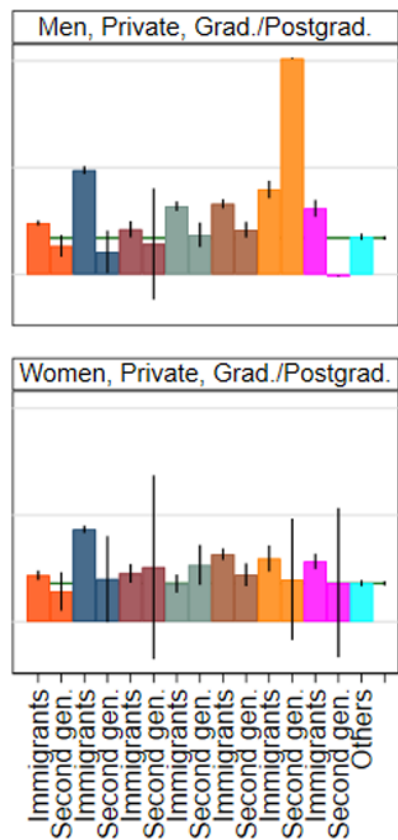
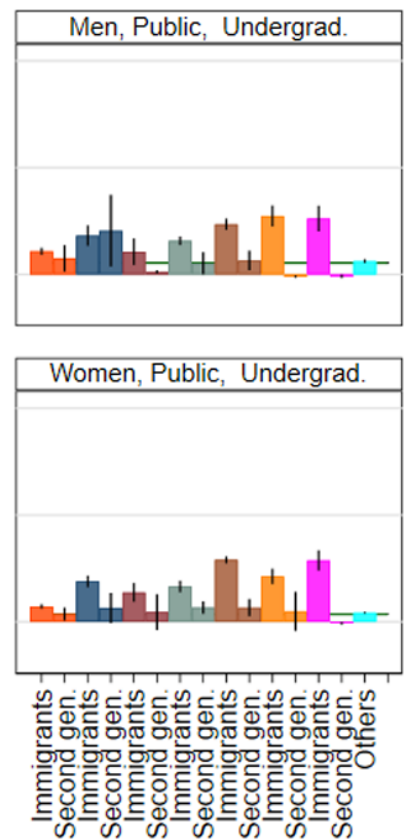
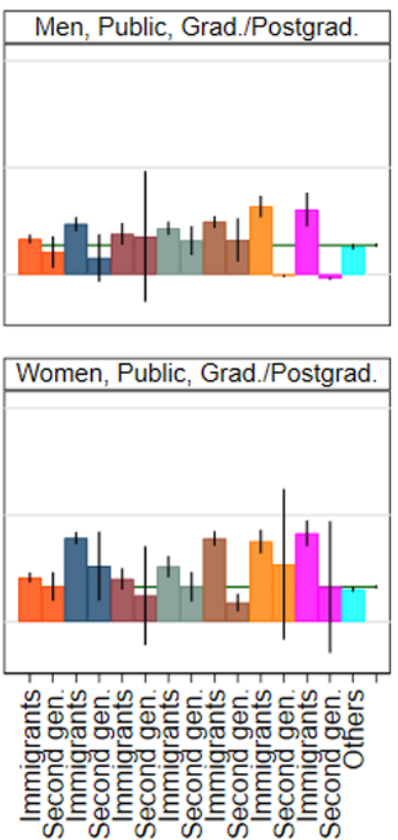

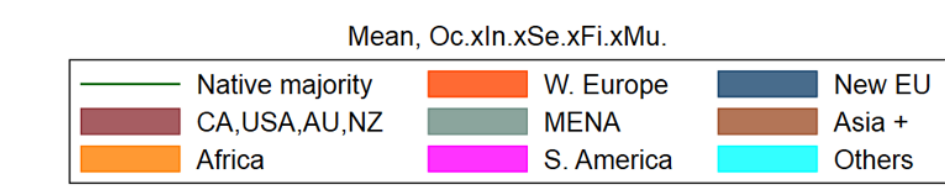

Coefficients. Control for reason for immigration

Figure A11. Differences in overqualification between immigrants and the second generation from seven country-of-origin groups, others, and the native majority by educational level. Note: 4 models estimated with age fixed effects and controls for stated reason for immigration (work, family, refugee, education, other reasons, a missing category, and a "not relevant" category). 